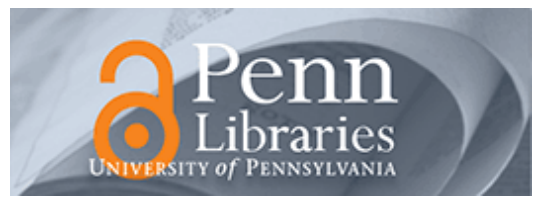

University of Pennsylvania

ScholarlyCommons

Management Papers

Wharton Faculty Research

$1-2015$

\title{
Leaning In or Leaning On? Gender, Homophily, and Activism in Crowdfunding
}

Jason Greenberg

New York University

Ethan Mollick

University of Pennsylvania

Follow this and additional works at: https://repository.upenn.edu/mgmt_papers

Part of the Management Sciences and Quantitative Methods Commons

\section{Recommended Citation}

Greenberg, J., \& Mollick, E. (2015). Leaning In or Leaning On? Gender, Homophily, and Activism in Crowdfunding. Academy of Management Proceedings, http://dx.doi.org/10.5465/

AMBPP.2015.18365abstract

This paper is posted at ScholarlyCommons. https://repository.upenn.edu/mgmt_papers/189

For more information, please contact repository@pobox.upenn.edu. 


\title{
Leaning In or Leaning On? Gender, Homophily, and Activism in Crowdfunding
}

\begin{abstract}
Female founders seek and receive less startup capital than male entrepreneurs. One reason for this disparity is a lack of female representation among funders of startups, and a potential solution is to increase the proportion of women in decision-making roles. Both the problem and the solution implicitly rely on homophily - that women will support other women given a chance. However, a lack of clarity over when and how homophily influences individual choices makes it uncertain when better representation is actually advantageous. Using data from crowdfunding, we empirically examine whether higher proportions of female funders lead to higher success rates in capital-raising for women. We find that women outperform men, and are more likely to succeed at a crowdfunding campaign, all other things being equal. Surprisingly, this effect primarily holds for female founders proposing technological projects, a category that is largely dominated by male founders and funders. This finding stands in stark contrast to expectations concerning homophily. A laboratory experiment helps explain how this pattern might emerge and allows us to theorize about the types of choice homophily driving results. We find that a small proportion of female backers disproportionately support women-led projects in areas where women are historically underrepresented. This suggests an activist variant of choice homophily, and implies that mere representation of female funders without activism may not always be enough to overcome the barriers faced by female founders.
\end{abstract}

\section{Keywords}

crowdfunding, entrepreneurship, gender

Disciplines

Management Sciences and Quantitative Methods 


\title{
Leaning In or Leaning On? \\ Gender, Homophily, and Activism in Crowdfunding*
}

\author{
Jason Greenberg, $\mathrm{PhD}$ \\ Leonard N. Stern School of Business \\ New York University \\ 40 West $4^{\text {th }}$ Street \\ Suite 706 \\ New York, New York 10012 \\ Phone: 212-998-0229 \\ E-mail address: jgreenbe@ @stern.nyu.edu \\ Ethan Mollick, PhD \\ The Wharton School \\ University of Pennsylvania \\ 2015 SD-DH \\ 3620 Locust Walk \\ Philadelphia, PA 19104 \\ Phone: 215-898-6361 \\ E-mail address: emollick@ wharton.upenn.edu
}

\section{Keywords: Sociology, homophily; crowdfunding, maker-movement}

\begin{abstract}
*Authorship is alphabetical; both authors contributed equally in developing this paper. For useful advice we would like to thank: Matthew Bidwell, Martine Haas, Gavin Kilduff, Nathan Pettit, Lisa Leslie, Cat Turco, Ezra Zuckerman, and seminar participants at MIT, NYU, Stanford GSB, and Wharton. Funding was generously provided by the Kauffman Foundation. All the standard disclaimers apply.
\end{abstract}




\title{
Leaning In or Leaning On? Gender, Homophily, and Activism in Crowdfunding
}

\begin{abstract}
Female founders seek and receive less startup capital. One reason for this disparity is a lack of female representation among funders of startups, and a potential solution is to increase the proportion of women in decision-making roles. Both problem and solution presuppose homophily - that women will support other women given a chance. However, a lack of clarity over when and how homophily influences individual choices makes it uncertain when better representation is advantageous. Using data from crowdfunding, we empirically examine whether higher proportions of female funders lead to higher success rates in capital-raising for women. We find that women outperform men. Surprisingly, this effect primarily holds for female founders proposing technological projects, a category that is largely dominated by male founders and funders. This finding stands in stark contrast to expectations concerning homophily. A laboratory experiment helps explain how this pattern might emerge and allows us to theorize about the types of choice homophily driving results. We find that a small proportion of female backers disproportionately support women-led projects in areas where women are historically underrepresented. This suggests an activist variant of choice homophily, and implies that mere representation without activism may not always be enough to overcome constraints.
\end{abstract}




\section{Leaning In or Leaning On? Gender, Homophily, and Activism in Crowdfunding}

Structural constraints imposed by gendered institutions help foster and maintain disadvantages for women (Blau, 1977; Pfeffer, 1983; Tilly, 1999; Reskin and McBrier, 2000). In attempt to address these constraints, researchers and policy makers alike have considered what causes gender disparities in organizational settings in general, with increasing attention focused on entrepreneurship in particular (Baron and Bielby, 1980; Carter, Shaw, and Wilson, 2007; Cohen and Huffman, 2007; Stainback and Tomaskovic-Devey, 2009; Brush et al, 2009; Huffman, Cohen, and Pearlman, 2010). Because entrepreneurs play a critical role in establishing organizations - creating cultures, establishing hiring protocols, and setting role expectations (Baron, Mittman, and Newman, 1991; Baron, Hannan, and Burton, 2001; Burton and Beckman, 2007; Beckman and Burton, 2008) - minimizing gender disparities in startup rates may have implications for a host of other organizational and labor market outcomes. For this reason, considerable effort has been devoted to understanding why female entrepreneurs seek and receive less startup capital, and how this inequality can be remedied. One possibility frequently mentioned by scholars as a proximate cause of this disparity is the significant underrepresentation of women in venture capital firms (Greene and Brush, 2001; Stuart and Sorenson, 2003a, 2003b; Harrison and Mason, 2007; Coleman and Robb, 2009; Miller, 2010; Canning, Haque, and Wang, 2012; see also Leiber, 2010).

A key proposal to mitigate gender disparities in various institutions and organizations entails increasing female representation in gatekeeping roles, such as venture capitalists (Kanter, 1977; Mühlenbruch and Jochimsen, 2013). The logic of this approach is rooted in notions of homosocial reproduction and homophily: given a choice of with whom to associate, men are more likely to prefer men, and women are more likely to prefer women. Hence, if the rate of 
women in decision-making positions in venture capital firms is increased so, too, should the rate of female entrepreneurs receiving funding who, in turn, should hire and promote more women in their organizations and industries.

There are, however, two reasons to doubt this logic. First, it presumes that women are, generally, more likely to support other women. However, audit and experimental studies suggest that women in male-dominated fields (and other minorities in similar positions) may favor members of dominant groups at similar rates as those in dominant groups (e.g., Nosek, Banaji, and Greenwald, 2002; Moss-Racusin et al., 2012; Milkman, Akinola, and Chugh, 2014). This finding potentially undermines the homophily-based logic that underlies targeted representation schemes, since it suggests that women may not necessarily prefer to support other women. Second, remedial approaches conflate two types of homophily—choice and induced—that may have distinct consequences. Induced homophily stems from structural and compositional features that lead to a lack of social connections and professional interactions among men and women, minimizing the likelihood that female entrepreneurs will have the opportunity to interact with predominantly male funders (McPherson and Smith-Lovin, 1987; Kossinets and Watts, 2009). Choice homophily, on the other hand, operates at the individual level, and refers to individualspecific reasons for supporting someone like oneself.

Unfortunately, the literature on choice homophily does not clearly define what the underlying motivation for preferential choice is, and there are several possibilities with distinct implications. First, and most common in the literature, a preference for similar people may be a superficial homophilic reaction: an inclination to support "someone who is like me" irrespective of a view of group-level need for such support. From this perspective, a female venture capitalist would favor female founders solely because they are women, and thus similar to the VC herself, 
rather than because of any feeling of connectedness to women as a class. A second possibility is that actors that share common characteristics, such as gender, may be more likely to share underlying preferences due to differential acculturation. From this perspective, a female VC should be more likely to support a project founded by a woman not because of a connection to people of similar gender, but because the founder's project appeals to the VC because the two women share similar tastes. If the latter is true, a similarity in gender is merely a correlate of homophilic outcomes, with shared underlying preferences as proximate cause and cultural forces as the fundamental driver. Finally, choice homophily may stem from common group-level concerns that are not rooted in similar product or service preferences. For example, women are underrepresented in a host of industries (e.g., technology, construction). A female VC might thus have a general disinterest in construction, but she may be inclined to support a woman in this industry as a result of her desire to help someone overcome barriers to advancement that she can sympathize or empathize with. These three possibilities imply different remedial strategies because their antecedents lie in different elements of social structure. Separating induced and choice homophily has historically been challenging, and distinguishing among forms of choice homophily is arguably even more so.

In this research we contribute to the literature on homophily by separating these distinct forms of choice homophily (McPherson and Smith-Lovin, 1987; Kossinets and Watts, 2009). To that end we use field data and a lab experiment to address the difficulty facing prior theoretical work in "purifying choice [homophily] or agency of structural factors" (McPherson, SmithLovin, and Cook, 2001: 420, note 5). We do so by accounting for common underlying product preferences rather than preferences for similar types of people, and by defining the boundaries of when specific types of choice homophily operate. In the process, we propose a specific form of 
choice homophily rooted in activism: the choice to support members of one's group to help ameliorate existing social structural deficits.

We use crowdfunding — defined here as internet-enabled provision of financial resources (Schwienbacher and Larralde, 2010) — as a strategic research site (Merton, 1987) where traditional financial gatekeepers such as venture capitalists and angel investors do not operate. Crowdfunding provides a setting that allows anyone to choose to help fund an idea they support, and allows founders the opportunity to easily access potential same-gender funders due to reduction in search costs and social constraints. This should significantly reduce induced homophily, allowing us to more clearly examine the role of choice homophily. We seek to answer two related research questions, one descriptive and the second predictive: Do women perform as well as men in crowdfunding? How do the specific forms of choice homophily relate to female performance, and what underlies choice homophily?

We find that crowdfunding does appear to reduce constraints for female founders seeking capital. In a fully-specified regression model controlling for a host of indicators of pitch quality and industry, we find that women are considerably more likely to successful raise capital than male founders. Contrary to expectations informed by prior literature, we find that this effect is not primarily based on female representation among backers alone. Instead, it is driven by the success of female founders developing technology projects, which is surprising as technology is an industry that is generally gender-typed male, and which has the fewest female funders (Lemons and Parzinger, 2007). Our analyses of field data from the largest crowdfunding platform suggest that, rather than the relatively high success rate of female founders being driven by the overall proportion of female backers in a category, it is instead dependent a small segment of female backers. Given the observational nature of these data, however, this inference is 
suggestive but not causal. In the final portion of this paper we test the hypothesis that a particularly motivated ("activist") subpopulation of women is driving the success of female founders. We do so using a lab experiment in which we determine how randomly assigned subjects evaluate the exact same real-world project while we manipulate the observable gender of the founder and interact it with the subject's activism orientation. We find that much of the unexpected marginal advantage for women may accrue to a small number of women founding technology projects, a category dominated by male founders and male backers.

This finding stands in stark contrast to expectations concerning homophily and representativeness as traditionally discussed in the literature on tokenism and value threat (Kanter, 1977; Cohen, Broschak, and Havemen, 1998; Duguid, Loyd, and Tolbert, 2012). Subsequent analyses provide an explanation to this theoretical puzzle: Although female backers disfavor investing in technology in general, this effect is contingent on the gender of project founders and the degree to which female backers believe that women are underrepresented in technology. It thus appears that a subpopulation of female backers is comparatively motivated to help female founders succeed in industry categories that are traditionally male-dominated. Thus a particular form of choice homophily (activist choice homophily) plays a critical role in determining the conditions under which social structural constraints are ameliorated.

These findings are of both theoretical and practical importance. Theoretically, we offer a distinction between several forms of choice homophily and clarify their conceptual bases. We also find that, though women outperform men in crowdfunding, increased representation of female funders does not in itself explain the success of female founders. Rather, the effect is driven primarily by an activist subpopulation of female backers that disproportionately supports female founders in areas in which women are historically underrepresented (thus evidencing 
activist choice homophily). This research thus provides evidence of the ways in which the internet can help ameliorate pervasive structural constraints (see generally Slade, 2013). It does so by affording access to a motivated type of same-gender supporter rather than just a greater proportion.

Given the underrepresentation of women in technology as founders, employees, and investors; the fact that venture capitalists tend to favor investing in technology; and the consistent evidence that female founders are less likely to raise venture capital, these findings are provocative and of policy relevance, an issue we will return to in the discussion.

To flesh out these arguments and evidence, the remainder of the paper is organized in two sections. We use a mixed-data approach to first develop theory concerning female success rates in crowdfunding using field data. Based on this theorizing, we use unique data from the largest and most prominent crowdfunding site in the world, Kickstarter, to conduct an exploratory analysis to inform our understanding of whether these social structural constraints bind on the internet as they do in traditional finance. A laboratory study is then used to test a hypothesis calibrated by the field-data concerning female funders' project assessments in which we can isolate forms of choice. We begin, however, by considering the array of social structural constraints facing female founders in general, and theorize about why crowdfunding may help address these issues as a technology that affords a new form of social organization (Davis, 2013).

\section{THEORY}

Social Structural Constraints and Startup Funding

Scholars have long considered how elements of social structure shape the opportunities and outcomes of social actors (Simmel, 1955 [1908]; Weber, 1968; Blau, 1977). While 
approaches to social structure are many and varied, underlying them is a focus on the generally durable implications that "extra-individual" factors such as positions, roles, relations, culture, and institutions have on outcomes of interest. Structural features (Blau, 1977; Baron and Bielby, 1980) and cultural presumptions and practice can, for example, constitute constraints or enablers of opportunity (e.g., Turco, 2012).

One constraint of interest is an apparent bias against women raising capital for new ventures. Basic descriptive statistics reveal a lack of female founders in high-growth businesses, with repeated studies finding that an extremely small percentage, between $1 \%$ and $6 \%$, of VCbacked companies have female founders depending on the sample and methodology used (Greene and Hart, 2003; Harrison and Mason, 2007; Canning et al., 2012). This compares unfavorably with the $40 \%$ of American businesses founded by women. This gender disparity also occurs within the funding network itself (Stuart and Sorenson, 2008), as only 14\% of all venture capitalists are women.

While there is general consensus among policymakers and scholars that this gap is likely detrimental, research on causes has not led to definitive answers. Data and measurement issues have historically made it difficult to distinguish direct gender discrimination from endogenous characteristics or from the social context in which female entrepreneurs operate (Shaw, Carter, and Lam, 2010). For example, women tend to start firms in industries that are less attractive to venture capitalists, tend to have lower levels of investor interest, and seek less capital (Carter and Allen, 1997; Coleman and Robb, 2009). A variety of studies on bank loans, controlling for these factors, have not found a direct effect of gender on the ability of women to secure loans (Buttner and Rosen, 1989; Fay and Williams, 1993; Carter et al., 2007). 
A number of scholars have, however, argued that attributing differences in capital raises among male and female founders primarily to differences in firm type or strategy obscures persistent structural discrimination against women (Brush, de Bruin, and Welter, 2009). Indeed, some evidence suggests that these differences in firm type by gender may be overstated (Brush, et al., 2009). Further, these disparities may be due to social constraints that shape career preferences (Correll, 2004) and may even lead to expectations among women that entrepreneurship is an inherently masculine endeavor (Baron, Markman, and Hirsa, 2001; Marlow, 2002). This more pessimistic view is supported by a recent study that found that women performing the same entrepreneurial pitch as men received considerably worse evaluations by professional investors than their otherwise identical male counterparts (WoodBrooks, Huang, Kearney, and Murray, 2014).

\section{Increased Representation Schemes Based on Homophily}

A common solution proposed to the social structural constraints faced by women founders is to increase the representation of women in decision-making roles (see generally Mühlenbruch and Jochimsen, 2013). In her classic work that draws on notions of homophily, Kanter (1977: 395) makes a related argument about the proportion of women inside an organization, demonstrating that the relative number of women is highly consequential for the success of those women individually, as well as women as a class. She concluded:

Yet it sees clear that numbers, especially relative numbers, can strongly affect a person's fate in an organization. This is a system rather than an individual construct - located not in a person but in how many people, like that person in significant ways, are present [...] a strong case can be made for number balancing as a worthwhile goal in itself, because, inside the organization, relative numbers can play a large part in further outcomes, from work effectiveness and promotion prospects to psychic distress. 
Increasing representation has also been proposed at the industry and population levels. Researchers have made quantitative and qualitative cases that increasing the proportion of women is critical to the success of individual women in areas as diverse as science (Nosek et al., 2009), law (e.g., Fuchs-Epstein, 1983), and the military (Pazy and Oron, 2001). A similar set of arguments has been raised about female entrepreneurs (Brush, et al., 2009). There is thus a common assumption that improving the number of female founders and funders would increase both the percentage of women willing to become entrepreneurs and their success in raising funds (Cain-Miller, 2010).

These approaches presume that many of the constraints on women are due to homophily (Stuart and Sorenson, 2008). Indeed, increased representation tries to address induced homophily by changing the social structure of an institution to increase the access of women to funders that look like them. This reduction in induced homophily is expected to lead to better outcomes for women seeking funding, as research has found that shared backgrounds facilitate the acquisition and interpretation of soft information because of common understandings and social networks (Bengtsson and Hsu, 2013), a factor which is even more critical since male investors tend to draw on mostly male networks for due diligence and deal acquisition (Sorenson and Stuart, 2003). In addition to the role of induced homophily in funding, homophily has been found repeatedly at the level of individual choice as well (McPherson, Smith-Lovin, and Cook, 2001). In the context of entrepreneurial funding, research has demonstrated the importance of homophily with respect to US venture capitalists' preference to collaborate with other venture capitalists with the same ethnic or employment backgrounds (Gompers, Mukharlyamov, and Xuan, 2012). Research also indicates that VCs prefer to invest in startups with co-ethnic executives (Hedge and Tumlinson, 2013; Bengtsson and Hsu, 2013). 


\section{Choice Homophily}

Increasing the relative representation of women depends on homophily as a mechanism to reduce systematic bias, partially because adding more female funders compensates for induced homophily by changing the social structure of venture capital. After addressing this structural problem, however, increased representation requires choice homophily among those female funders in order to ensure that the gender gains among funders are translated to the funding of female entrepreneurs. A lack of clarity in the literature about how choice homophily operates, however, makes it unclear what mechanisms may actually be at work when increasing representation. Indeed, the logic of homophily in investing operates via several mechanisms, which are rarely measured directly, leading to an identification problem. We seek to differentiate among three types of choice homophily in order to better understand and clarify the concept.

The first is what we call "interpersonal choice homophily." The idea that "birds of a feather flock together" is an ancient concept, and one reflected in the very term homophily self-love. Indeed, Aristotle's Nichomachean Ethics says similarity is a source of friendship, as "we love those who are like ourselves." Friendships and other interactions are most common among similar people because individuals have a natural common liking for each other (Verbrugge, 1977; Lazarsfeld and Merton, 1954, Ingram and Morris, 2007). Scholars have identified a variety of dimensions under which this sort of interpersonal choice homophily could operate including homophily based on shared values (Lazarsfeld and Merton, 1954), shared status (Podolny, 1993), and a variety of other characteristics (McPherson, Smith-Lovin, and Cook, 2001). We group all of these types under the single label of interpersonal choice homophily because they all operate through the dyadic identification of common characteristics. 
In entrepreneurship, this is reflected in research that demonstrates that founders looking to form teams are drawn to those who are similar to them (Ruef, Aldrich, and Carter, 2003; Greenberg, 2014),

A second type of choice homophily is "shared preference choice homophily." In this case, the preference is not for similar individuals but for a product or service created by an individual of a similar background. Individuals of the same gender may share similar underlying preferences, making it easier for funders to see the need for a particular product or service created by someone of their gender. This can be explicit, as in a cosmetic targeted at women, or more subtle, as in the case of movies or books that take advantage of shared sensibilities to target women. A female entrepreneur may therefore be more likely to propose a project with greater appeal to a prospective female backer.

Both of these forms of choice homophily are first-order effects, in that they result from a direct connection between one person and another person, either directly or through shared preferences. A third form of choice homophily, what we call "activist choice homophily," relies on group-level interests rather than interpersonal attraction or common taste. Activist choice homophily may facilitate a greater desire on the part of the backer to see the entrepreneur succeed because she can either sympathize or empathize with the entrepreneur's position and, thus, challenges. From this perspective shared product or service preferences is not essential. Rather, the funder must believe that that the founder is facing constrained access to an outcome that can be attributable to a salient, common group-level characteristic such as gender.

These three forms of homophily all operate differently, but they have generally been conflated in the literature on representation, homophily, and their effects on outcomes of social 
scientific interest. This may explain some of the inconsistent results concerning the value of homophily and representation in improving outcomes for women. For example, as might be predicted by activist choice homophily, but not by interpersonal or preference choice homophily, structural features pertaining to representation can exert uneven effects. Cohen, Broschak, and Haveman (1998) studied the link between the sex composition of organizations in the California savings and loan industry. They found that representation matters, but in nonlinear ways as women are more likely to be hired or promoted to a specific job-level that already includes a high proportion of women. This tends to occur when there is a substantial minority of women in the organization position directly above that to which they apply. However, this is not the case when women represent the majority of said position. Second, women in positions to advocate for other women as a result of their status positions have to consider status maintenance, which may restrain in-group advocacy. In another study, Duguid, Loyd, and Tolbert (2012) find that contrary to the underlying logic of interpersonal choice homophily, women and racial minorities in high status work groups will not necessarily advocate for same gender or race colleagues due to value threat - that is, their personal concerns for being valued by their work group. (On organization gender composition effects see generally: Tolbert and Oberfield, 1991; Reskin, McBrier, and Kmec, 1999; DiTomaso, Post, and Parks-Yancy, 2007).

In order to assess the expectation that increased female representation would lead, in turn, to greater female success in seeking startup funding, we examine a context in which women and men seek funding for a variety of projects—crowdfunding. Because there are no formal gatekeepers in crowdfunding, and, in principle, anyone can choose to back any project, induced homophily is significantly minimized and choice homophily is easier to observe and analyze. By looking at subpopulations where women or men are better represented as both founders and 
funders, we can assess whether representation lowers social structural barriers, and which form of choice homophily operates.

\section{CROWDFUNDING AND FEMALE FOUNDERS}

Crowdfunding refers to a variety of different ways entrepreneurs (cultural, social, and for-profit) can fund their efforts by drawing on relatively small contributions from a relatively large number of individuals using the internet without standard financial intermediaries (Schwienbacher and Larralde, 2010; Mollick, 2014). Crowdfunding embraces a wide range of potential funding needs. Many crowdfunded projects seek to raise small amounts of capital for one-time use such as a particular event. In these cases, capital is often provided by friends and family, and crowdfunding is simply a mechanism for gathering funds. Increasingly, however, crowdfunding appears to be a viable source of entrepreneurial seed capital (Schwienbacher and Larralde, 2010), allowing entrepreneurs to raise the initial funds required to start their new ventures. In one study, Mollick and Kuppuswamy (2014) found that $90 \%$ of successful crowdfunding projects turned into ongoing ventures, while the success of crowdfunded ventures like virtual reality firm Oculus Rift, bought in 2014 by Facebook for $\$ 2$ billion, suggests that crowdfunding is a viable path to initial venture financing for high growth ventures as well.

Despite serving as a source of venture funding, crowdfunding works differently than most other methods of entrepreneurial finance. For example, rather than the private pitches that characterize venture capital, crowdfunding is open and "democratic" in nature. Individuals seeking funding publically list their projects, along with a fundraising window and their desired capital raise (called a goal in crowdfunding). This public information also includes a description of what the founders hope to accomplish with the money, rewards they offer in return for funding, and any other material they hope will make the case for their efforts, including videos 
and pictures of prototypes. The project initiator then tries to promote their project, using social networks, media, influential individuals, and other means. The goal is to attract individual backers, or funders, that will pledge to support the project if the fundraising goal is met. There is often a substantial dialogue that develops between project proposers and potential backers. Comments, questions, and discussions take place on both the crowdfunding website, as well as external venues such as Twitter and Facebook. If the project achieves its goal, the money is transferred to the proposer who has scant legal obligation to the backers to complete the project, though, in practice, almost all projects make a serious effort at achieving their goals (Mollick, 2014).

By removing traditional gatekeepers to finance, such as VCs, and increasing pools of potential supporters, crowdfunding potentially mitigates the social barriers faced by femalefounded (or cofounded) ventures by "democratizing entrepreneurship" (Kaufman, Kassinger, and Traeger, 2013). In crowdfunding backers choose to put money behind founders for projects that are not yet complete. They typically do so as a way of pre-ordering a product that does not yet exist. However, there is no enforceable contract or requirement that founders use the money in the way backers intended. Consequently, backers evaluate founders much as investors do looking for signals of future capability, reliability, and quality (Mollick, 2014). The promise of crowdfunding is that by reaching out to a large pool of potential backers over the internet without face-to-face contact or networking, female founders may be able to overcome historical discrimination in accessing financing to start new ventures (see, e.g., Slade, 2013).

There are a number of possible ways in which crowdfunding may help individuals overcome pervasive social structural constraints associated with gender. One is that individuals might transcend, in whole or in part, their ascriptive characteristics and present themselves as 
they see fit in online space (Yee and Bailenson, 2007), or as one famous New Yorker cartoon featuring a canine using a computer mouse put it, "On the internet, nobody knows you're a dog." The potential "democraticizing" power of crowdfunding has animated and inspired many in the popular press and industry. Some observers have argued that crowdfunding unleashes individual interests and market forces that may help overcome discrimination. That is, that crowdfunding platforms make projects equally visible where they either thrive or die based on merit (see, e.g., Slade, 2013). Such a view, presumes, however, that no (biased) inferences based on ascriptive characteristics and industry categories are made, which seems unlikely.

In line with this expectation, it is clear that gender remains relevant in crowdfunding. Among the top funded projects are those with explicitly gendered goals (such as GoldieBlox, an engineering kit for girls) and those which have inspired concerns over potential misogyny (a guide to "picking-up" women was removed from Kickstarter after it was viewed as inappropriate). Indeed our study indicated that the gender of the project founder on Kickstarter was clear in the majority of cases (>71\%), even it was not immediately apparent from, for example, a picture of the creator.

An alternative explanation consistent with the same observable outcome proposes that even if the internet does not reduce the bias of individuals, it may enable founders to access a sufficient number of backers who would be willing to support the founder. That is, the internet affords the possibility of accessing a deeper pool of like-minded individuals than is typically possible in geographically or socially constrained search (see generally Fernandez and Su, 2004, Agrawal, Catalini, and Goldfarb, 2011). More important than the reduction of search constraints, crowdfunding also eliminates the induced homophily inherent in the structure of current funding mechanisms. This allows us to more directly observe choice homophily. 
In light of prior theorizing on homophily and crowdfunding, we have several empirical expectations. First, as crowdfunding backers remain mostly male (Robb, Marom, and Sade, 2013), we expect that if choice homophily operates as expected, then women will be generally disadvantaged in raising funds. Second, if relative representation helps explain the opportunity available to female founders, we would expect that crowdfunding categories where women are more highly represented as both founders and backers would result in higher success rates for women as female backers act on choice homophily. We test these assumptions below. Our results point to the opposite of both of these expected outcomes, for reasons that we will discuss shortly and will return to in Study 2 where we further distinguish among variants of choice homophily with a laboratory experiment.

\section{ANALYSIS}

\section{Study 1: Kickstarter}

Data

To test these questions we employ data on projects from Kickstarter, the largest crowdfunding site in the world. We randomly selected 1,250 proposed projects from five categories: Gaming, technology, film, fashion, and children's books. These industry categories were chosen based on the gender distribution of backers and founders with first two being predominantly male; the third being more evenly weighted; and the last two including higher proportions of women as founders and funders (see also Robb, Marom, and Sade, 2013). It is worth noting that, given these categories, the impact of homophily may be magnified by a second effect: industry typing. Theory in sociology and psychology concerning gender-typing of occupations and underlying schemas predicts that people often hold conscious or unconscious biases about what gender is the archetype employee in a particular occupation or industry (White, Kruczek, Brown, and White, 1989; Ridgeway, 1997; Williams, 2000: Ch 3; Gorman, 
2005; Heilman, 2012). A statistically discriminating backer should thus favor entrepreneurs with group-level characteristics they believe predict better ability to deliver the promised project (see generally Becker, 1959; see also Arrow, 1972, 1973; Fernandez and Greenberg, 2013). ${ }^{1}$ Examples include a male entrepreneur in the male-dominated technology industry (e.g., Whittington and Smith-Doerr, 2008), or a female entrepreneur in children's books. This industry-typing effect reinforces expectations that women should perform best in those categories where they are best represented since they also match industry norms, and that they should perform worst in areas where they are least represented, since those violate industry norms.

Information was collected on the characteristics that may influence funding decisions. We also analyzed each project pitch to extract the gender of each founder (or co-founders if a team). Data on each project's backers - more than 250,000 across all the projects in our sample — were scrapped, cleaned, and coded for geography and gender information. The combination of founder and (funder) backer gender and geography data enable us to calculate a host of metrics characterizing the gender of each project's founder(s) and its geographical location as it relates to its backers.

Several restrictions were imposed in defining the sampling frame. First, only projects originating in the US are permitted, consistent with Kickstater policies during the study window. Second, we eliminate projects that seek less than $\$ 5,000$. This restriction is imposed because projects with funding goals lower than $\$ 5,000$ may draw a disproportionate share of backers who

\footnotetext{
${ }^{1}$ It should be noted at this point that there are different theories of statistical discrimination. Some assume that productivity differences are at the first moment whereas others assume it is at the second moment (Aigner and Cain, 1977). For our purposes, this distinction does not have a bearing on theory development or empirical tests. It should be further noted that investors may have biases concerning what characteristics including gender may have a bearing on (or proxy for consequential unobservables predicting) being a good entrepreneur. Assuming this bias is in favor of male entrepreneurs, homophily in the case of male investors and heterophily in the case of female investors picks this up (e.g., Marlow, 2002).
} 
are friends and family members, thus biasing results (Mollick, 2014). Finally, each project in our sample includes a pitch video concerning its proposed products or services.

\section{Measures}

\section{Dependent variables}

Two outcome measures are employed to describe outcomes in the Kickstarter database.

The first indicates that the project was successfully funded by meeting or exceeding their goal (1=yes, $0=$ no). Approximately 32\% ( $\mathrm{SD}=.466)$ of projects succeeded in this respect.

Figure 1 Panels A and B

A second measure represents the fraction of a project's backers who are female (female backers/total backers). This data was scrapped from Kickstarter and coded algorithmically using the genderize.io tool by comparing first names with a database including 86,710 distinct names across 81 languages with known gender distributions. ${ }^{2}$ Figures 1 through 3 present the unconditional distributions of each of these outcome measures.

As expected, female founders are more likely to found projects in fashion and publishing, followed by film. Female founders are also underrepresented in technology and games, consistent with expectations. The same industry distribution is evident for female backers. Figures 2 and 3 suggest, however, that female backers' industry preferences are contingent on the gender composition of the project's founder(s), thus revealing suggestive evidence of choice homophily. Figures 2 and 3 also reveal that female founders outperform male founders,

\footnotetext{
${ }^{2}$ A parameter was generated concerning the probability that a specific name-gender attribution (male or female) was correct. In $90.57 \%$ of cases the probability that assignment was correct exceeded $90 \%$, suggesting a high degree of accuracy. In sensitivity analyses we reran models including the measure for percent female backers excluding cases below the $90 \%$ threshold. Results remained consistent with those presented here.
} 
particularly in technology. Female funders exhibit backing patterns consistent with these patterns.

Figure 2.

Figure 3.

\section{Independent variables}

We specify intersection effects (Goodman, 2002; Greenberg, 2014) as the key predictors. These measures represent each of three cells in a two-by-two table with one or more female or male founders on the row or column. One measure thus denotes that a project has at least one female founder and no male founder. A second reflects a project that has at least one male founder and no female founder. The third represents a project with at least one male and at least one female founder. The omitted category reflects projects that do not have any identifiably gendered founders. This occurs when the project lists and/or graphically portrays a corporate entity, un-gendered avatar, mascot, or other non-human entity as the founder. Data on the gender of the founder(s) were derived by visually analyzing and coding the apparent gender of each founder in each project ${ }^{3}$. Four research assistants (two male and two female) coded each project, and the kappa value of inter-rater reliability for gender exceeded .90 (with levels of agreement at 94\% or higher; z-ratios $>30$; and $P<.0001)$.

\section{Controls}

The key inferential challenge we face with respect to the Kickstarter data is ensuring that factors correlated with both female/male founders and performance are accounted for. That is, that projects founded by at least one female founder and no male founder or vice versa do not

\footnotetext{
${ }^{3}$ Results were robust to other measurements of founder gender, including the names of founders in the project and the appearance of founders in videos promoting the project.
} 
differ in terms of the quality of their pitches or projects. We include a range of controls to address this concern.

We include measures that capture the observable quality and characteristics of the project pitch as found in prior research (Mollick, 2014). Measures include: whether the project was featured on the Kickstarter site, the number of spelling errors in a pitch, and the degree to which founders provided timely updates to their backers within three days of starting a campaign. A measure of the (ln) funding goal is also calculated as it constitutes both a hurdle for successfully funding a project, as well as a signal to potential investors. We also include a measure of the founder's network size as reflected in Facebook connections based on the logic that founders with larger networks are comparatively better positioned to access financing on the site. To reduce skew, we transform this measure by taking the natural log.

In robustness checks we also included several measures to assess the competitive environments in which funding efforts were made. We generated locations for backers and project creators. We used measures of the local geography in which the entrepreneurs are located including the population size, number of artists, and average income in the closest metropolitan statistical area (Stuart and Sorenson, 2008; Brynjolfsson, Hu, and Rahman, 2009). ${ }^{4}$ These measures did not significantly alter results or improve model fit, so we do not present them in the main analyses (but they are available upon request). Summary statistics and pairwise correlations are presented below.

Table 1. Summary statistics: Kickstarter

\footnotetext{
${ }^{4}$ In analyses not presented here but available upon request we determined whether projects founded by women attract female backers from further distances thus overcoming constraints imposed by space (see generally Fernandez and $\mathrm{Su}, 2004)$. The model provides weak evidence contrary to this possibility.
} 
Table 2. Summary statistics: Experiment

\section{Statistical methods}

To determine whether a project is successfully funded we use a logistic regression model. As noted above the key predictors are intersection effects indicating that the project includes: at least one female founder, but no male founder; at least one male founder, but no female founder; and at least one female founder and one male founder. Additionally, we include the fractional measure of female backers/total backers as a predictor (see below), and also interact that measure with the intersection effect representing a project with at least one female founder but no male founder.

To test the role of choice homophily, we treat the fraction of backers who are female as the outcome measure. Given the bounded nature of this measure in the unit interval, a fractional logit model is specified (see, e.g., Papke and Wooldridge, 1996). Maximum likelihood estimation is used here to optimize the likelihood function. Key predictors and controls are similar to those specified above. ${ }^{5}$

\section{FINDINGS: KICKSTARTER}

Table 3. Fraction of Female Backers Supporting Project

Table 3 presents coefficient estimates from the fractional logit model predicting the proportion of backers who are female. The first model presented to establish a baseline is an unconditional model that includes the variables reflecting project industries. The omitted

\footnotetext{
${ }^{5}$ In robustness checks we estimate this equation using quasi maximum likelihood and OLS. Results are consistent across estimation techniques. See Table A1 in the appendix.
} 
category is film - the category in which we observed the most even distribution of female and male founders and backers. Coefficient estimates suggest that the share of backers who are females is greater in publishing $(b=0.341, P<.01$ (two-tailed test)) and fashion $(b=0.435, P$ $<.001$ (two-tailed test)) than in film, and less in games $(b=-1.15, P<.001$ (two-tailed test)) and technology $(b=-1.091, P<.001$ (two-tailed test)). These estimates remain stable in model 2 when we include the controls.

Model 3 includes the intersection effects denoting a project or founding team with just female, male, or female and male founders. This model is also unconditional to establish a baseline. Coefficient estimates suggest that a project founded by at least one female, but no male founder draws a significantly greater proportion of female backers $(b=1.118, P<.001$ (two-tailed test)) than a project in which no founder gender is evident, as may be the case with a project that has a corporate logo or un-gendered avatar depiction of the founder. The coefficient for a male founder but no female is small in magnitude $(b=.03)$ and does not achieve statistical significance at conventional levels. These results suggest that female backers are more likely to back projects founded by females, indicating choice homophily writ large. However, this model does not account for industry categories or controls.

Model 4 includes both. Coefficient estimates for gender of founder(s) remain consistent with prior models: Projects with a female founder but no male founder attract a greater proportion of female backers than projects founded by individuals who do not reveal their gender (the baseline), or a project pitched by at least one male founder but no female $\left(\chi^{2(1)}=36.9, P\right.$ $<.0001)$. These results suggest that female funders do indeed prefer to back projects founded by women, i.e., choice homophily. It should be noted that in these data the opposite does not appear to be the case. Male funders do not appear to have a preference for male founders. 
Models 5 and 6 include interaction terms between female founders and the specific industry categories. The estimates reveal that save for a marginally significant estimate for technology $(b=.5, P<.05$ (one-tailed test)), female backers do not appear to favor female founders in any specific industry category relative to the baseline, which is inconsistent with the idea that common underlying product preferences underlies choice homophily.

Table 4. Predictors of Successful Funding Raise

Table 4 presents exponentiated coefficients from a logistic regression model predicting the odds of a project achieving its fundraising goals. As before, we begin by building intuition concerning baseline effects for industry categories in models 7 (an unconditional model) and model 8 (a conditional model). Results reveal that relative to the baseline, film, projects in the other industries are less likely to achieve their funding goals. In the conditional model (8), the odds-ratio for children's books is .516 ( $P<.001$ (two-tailed test)); it is .546 for fashion $(P<.001$ (two-tailed test)); .666 for technology $(P<.05$ (one-tailed test)) and .85 (ns) for games.

Model 9 is an unconditional model that includes only the founder gender variables. Results suggest that projects founded only by a woman (or women) have $40 \%$ greater odds of a successful funding raise, net of other factors. The coefficients for all male teams and those for mixed-gender teams are insignificant. Model 10 includes controls as well as the industry fixedeffects. With these measures included, the odds-ratio for projects founded be a female (or females) is 1.59 ( $P<.05$ (two-tailed test)), an estimate that is significantly larger than that for projects founded by a male (or males) $\left(\chi^{2(1)}=4.38, P<.05\right)$.

Model 11 includes the measure of the percentage of backers who are female, and model 12 includes interactions of this term with the measure of all female projects, which can be 
interpreted as a measure of homophily. Interactions are also specified for female founder(s) by industry categories.

Linear combinations of the untransformed logit coefficients for proportion of backers female, female founder(s) and no male founder, and homophily suggest that the impact of homophily varies somewhat with the percent of female backers. The combined $\operatorname{logit}^{6}$ for a successful fund raise when the proportion of female backers is $10 \%$ is $1.086(\mathrm{se}=.523$; z-ratio $=$ 2.08 ); for $25 \%$ it is 2.462 ( $\mathrm{se}=.791$; $\mathrm{z}$-ratio $=3.11)$; for $50 \%$ it is $2.31(\mathrm{se}=.78$; $\mathrm{z}-$ ratio $=2.96)$, and for $75 \%$ it is 2.157 ( $\mathrm{se}=.776$; $\mathrm{z}$-ratio=2.78). Results also indicate that this effect is driven in part by the performance of projects in technology founded by female founders. The untransformed coefficient for the interaction denoting at least one female founder and no male*technology is 1.468 (se=.752; $P<.05$ (two-tailed test)). Interpreted as a predicted probability, the margin is .647 , which compares with a figure of .354 for the baseline (i.e., film and no observable founder gender). The figure for technology and no observable gender is .284.

Choice homophily appears to be an important factor shaping this relationship. For a technology project founded by women (with other industry and founder gender variables set to 0 ) the linear combination equals 2.385 (z-ratio=3.04). If we remove the effect for homophily by setting the coefficient for it to zero, the linear combination estimate falls to .595 (se=.677; zratio $=0.88$ ). This difference reveals the importance of female backers for female founders in technology. Finally, model 13 includes a two-way interaction between mean proportion of female backers and technology. When interpreted with the results of table 3 above in mind, this coefficient estimate suggests that female backers generally disfavor technology in general. ${ }^{7}$

\footnotetext{
${ }^{6}$ Linear combinations of logits are additive, whereas those for odds-ratios or predicted probabilities are multiplicative (and can differ). For ease of calculation we present the former.

${ }^{7}$ Unfortunately, due to small cell sizes, we cannot reliably estimate a three-way interaction between mean $\%$ female backer*tech*female only projects.
} 
Considered collectively, these results imply that, first, female backers avoid technological projects, except if those projects are founded by female founders, in which case they exhibit choice homophily. Second, we find that female founders in technology are considerably more likely to achieve their funding goals in Kickstarter. This is not the case in the other industry categories - fashion, publishing, and games - which is inconsistent with notions of common product preferences, and thus shared preference choice homophily. ${ }^{8}$ Connecting these two findings, it appears female backers are responsible for helping female founders succeed in specific industry categories that women backers generally disfavor. These results are highly suggestive of choice homophily (either interpersonal or activist) that is not based on underlying product preferences and is counter to industry typing. However, our data are not detailed enough to conclusively account for each dimension of choice homophily. To do so, we return to theorizing, and then turn to a laboratory study in order to better understand the field outcomes.

\section{AN EXPERIMENTAL ANALYSIS OF CROWDFUNDING AND ACTIVIST CHOICE HOMOPHILY}

Our results concerning choice homophily and representation are the opposite of conventional expectations. First, we find that women outperform men in crowdfunding despite constituting a minority of funders or backers, which suggests that induced homophily is mitigated in crowdfunding. More critically, the difference in performance is not driven by the industry categories where female founders and backers are most represented, but rather where they are least represented. Indeed, it appears that almost all of the homophilic effect comes from the technology category where women are relatively rare as either founders or funders. This is

\footnotetext{
${ }^{8}$ The interaction for tech*at least one female, no male founder differs from the analogous measures for fashion $\left(\chi^{2(1)}=3.99 P<.05\right)$ and publishing $\left(\chi^{2(1)}=4.31, P<.05\right)$. Note further that in a model not presented here but available upon request we include a measure of the $\ln$ (median distance) between project and backers. Inclusion of this coefficient amplified the effects of homophily and the success of female founders in tech.
} 
inconsistent with common underlying product preferences driving preference choice homophily (as well as with gender typing, generally). At the same time, we find little evidence of bias or homophily among men towards other men. This raises the question: What could account for the pattern of results we observe?

One possibility discussed above is that, rather than observing interpersonal choice homophily, we are instead observing activist choice homophily. This suggests, in line with findings that minority groups may not support their own members once given positions of authority (Milkman et al., 2014), that mere representation does not always lead to increased rates of success. A slightly different argument with the same observable consequences is suggested by Cohen, Broschak, and Haveman's (1998) finding that women tended to progress in managerial positions if the level of the hierarchy directly above their position had a sizeable minority but not majority of women. One possible explanation for this apparent paradox is that once they achieve (near) equal representation, the imperative to help other women is diminished. On this possibility Cohen, Broschak, and Haveman argue that (1998): “[...] when women and men are nearly equally represented the advancement of women seems to warrant no special effort. Hence highly placed women may feel no need to push for hiring or promoting women into lower level positions."

To the extent this is true, this implies those perceptions of structural deficits and the motivation to ameliorate them moderate action. Thus, absent a belief that women require assistance, help will not be forthcoming as feelings of common identity are likely not triggered (Hogg and Terry, 2000). We argue that crowdfunding supports a variety of motivations for funders, and one such motivation is, for some subpopulation of female backers, to support fellow women in areas where they are traditionally underrepresented - activist choice homophily. From 
this perspective, the value of internet-enabled crowdfunding is not necessarily the fact that it reduces induced homophily by allowing women access to more female funders in relative terms. Rather, the value of crowdfunding is that it enables access to a pool of potential female backers particularly inclined to support women in industry categories in which they believe women to be underrepresented.

We therefore propose that activist choice homophily, rather than improved numerical proportionality in itself, can explain the disproportionate success of women in industry categories in which women are underrepresented. In this case, we can define activist choice homophily narrowly as the degree to which individuals see a need to support under-represented groups combined with the belief that women are under-represented in technology. We thus expect to observe that:

Hypothesis 1: Activism positively moderates the propensity of women to support female-led projects in industries in which women are underrepresented

To test this hypothesis, and thus to help clarify why backers might fund the projects they do, we employ a laboratory experiment. The experiment enables us to hold constant all elements of the project while randomly manipulating the ostensible gender of the founder. This is important because a correlation between the gender of the founder and funder might arise for distinct reasons commonly subsumed under choice homophily that have not been separated definitively in prior work. First, a preference for same-gender founders might operate. This is the essence of interpersonal choice homophily, a phenomena that has been the subject of considerable research in sociology, if often as a contrast category vis-à-vis induced homophily (for a general, if now dated, review see McPherson, Smith-Lovin, and Cook, 2001; Kossinets and Watts, 2009). Second, female (or male) founders and funders might have similar preferences 
for products or services, which we have called shared preference choice homophily. At the extreme this implies that founder gender is spuriously related to funding outcomes. Without an experimental setup it is hard to distinguish between these possibilities. Because we manipulate the observable gender of the founder for the same exact product pitches we can tease apart these subtle but important differences. Finally, we collect data concerning backers' activist inclinations that we employ as a moderator to determine whether activism is a plausible explanation for observed choices.

\section{Study 2: Laboratory experiment}

\section{Procedure}

To determine what mechanism might underlie the observed findings we designed and conducted a laboratory experiment informed and calibrated based on the Kickstarter data. We began by selecting two Kickstarter projects that were successfully funded and not targeted at a specific gender group. One was in the technology category (an invention kit to create touchpads out of everyday items) and the other in fashion (custom jeans for either men or women). Each represented the single most popular (in terms of number of backers) project in their respective industry categories that did not have an obvious gendered target backer or consumer. We disguised the actual designers of these projects (though we revealed them after the completion of the experiment to ensure proper credit), and instead randomly presented subjects with either of the two projects, with one of two potential founders of each gender.

We therefore used a 2 (Project Category) x 2 (Founder Gender) x 2 (Subject Gender) design. Each subject came to the lab and sat down at a computer. They were asked basic demographic questions, and information about their experience with crowdfunding. They were 
then taken to a screen where they were randomly shown either of the two projects with either of the two creators.

To establish the founder-gender conditions, the only variation between the two was the name and picture of the founder. We took the following steps to account for potential confounds. First, we selected photographs of individuals of the same race (Caucasian) and ethnicity (Scandinavian). Second, we relied on research concerning attractiveness to ensure that the two photographs did not vary substantially in that respect. We thus employed photographs of individuals deemed of average attractiveness in research concerning facial expression and evaluation (Lundqvist, Flykt, and Ohman, 1988; Oosterhof and Todorov, 2008). Third, to ensure that signals of agreeableness do not confound results both photos depict individuals with a similar pose and smiling expression. Fourth, to ensure that issues of fashion (and related signals) did not differ, the male and female were photographed by the original researchers with a similar grey t-shirt. Finally, we selected faux names for each founder that were the most popular for the experimental subjects' age range_-Jessica and Michael—along with the most common surname in the United States that was attributed to each (i.e., Jessica Smith, Michael Smith). Exhibit A in the Appendix provides an example of the project page and the photographs we used to manipulate the observable gender of the founder.

On the same screen as the project, experimental subjects assigned to either condition were asked to agree or disagree on a five point Likert scale with the following question: "The project is a good idea." Given that the only variation within the project category was the gender of the creator, we reason that variations in assessments concerning whether the project is a good idea should capture any general biases based on gender. 
Once subjects were done with this question, ${ }^{9}$ they were asked additional questions about their degree of activism pertaining to the under-representation of women in technology or fashion to determine the extent to which it moderates the relationship. To assess general activism, we asked: "I would prefer to support a project by someone who is under-represented in an industry." To assess technology activism, we asked: "Women are unfairly under-represented in high technology industries." We coded subjects as being activists if they demonstrated agreement with these statements (consent greater than 3 out of 5 on a standard Likert scale). The technology activism measure is highly correlated with the under-representation measure $(r=.944$, $P<.0001$ ), so we only include the former in the models below. Using the other measure, or the combination, yields similar results (available upon request).

In our sample, $39 \%$ of respondents indicated they agree or strongly agree that women are underrepresented in technology $(\mathrm{SD}=.489)$. Slightly more than $41 \%$ of women agreed or strongly agreed with this statement. The corresponding figure for men was $31.17 \%$. By contrast, only 7.7\% of respondents $(\mathrm{SD}=.267)$ agreed or strongly agreed that women are underrepresented in fashion $-10.34 \%$ of women and $2.63 \%$ of men. Paired t-tests reveal that these figures are statistically different overall $(\mathrm{t}-\mathrm{ratio}=8.524)$, for women $(\mathrm{t}-\mathrm{ratio}=6.878)$, and men $(\mathrm{t}-\mathrm{ratio}=5.031)$. The correlation between the fashion and technology activism measures is .18 $(P<.05)$ for female subjects, and .07 (ns) for male subjects.

\section{Subjects}

Our experiment was administered to students at an elite private school in the Northeastern region of the US in March 2014. The average age of a respondent was 20.48

\footnotetext{
9 This question was asked after the subjects evaluated the project to ensure they were not primed or sensitized to issues of representation, which may have impacted evaluation biasing results.
} 
$(\mathrm{SD}=1.678 ; \min =18, \max =28) .35 .7 \%$ were Asian, $33 \%$ white, $14.7 \%$ black, $6.3 \%$ Hispanic. The remainder declined to answer this question. Approximately $15.2 \%$ indicated prior experience backing a crowd-based project.

Analysis

To test the hypothesis concerning activism using the experimental data we employ the following model:

$$
\begin{aligned}
\text { Good idea }=\beta_{0}+ & \sum_{p=1}^{P} \beta_{1}(\text { Female founder }) \\
& +\beta_{2}(\text { Tech })+\beta_{3}(\text { Tech activist })+\beta_{4}(\text { Female founder }) *(\text { Tech }) \\
& +\beta_{5}(\text { Female founder }) *(\text { Tech activist })+\beta_{6}(\text { Tech }) *(\text { Tech activist }) \\
& +\beta_{7}(\text { Female founder }) *(\text { Tech }) *(\text { Tech activist })+\beta_{8}(\boldsymbol{X})+\mathcal{E}
\end{aligned}
$$

We estimate separate models for male and female subjects. Coefficients were compared across models to determine whether female and male experimental subjects differed with respect to their beliefs that the same project was a good idea as a function of the experimentally manipulated observable gender of the founder and their own stated beliefs concerning the underrepresentation of women in technology. To simplify assumptions underlying cross-model comparison and to ease interpretation, we estimate this model with OLS. In Table A2 we present analogous results from an ordered probit model. As noted in the bottom panel of that table an approximate LR- $\chi^{2}$ of equality of coefficients across response categories is insignificant, suggesting that the assumption of parallel regressions is appropriate. Note also that results are substantively similar to those presented with the OLS models. Hence, we focus on the latter below for the reasons outlined.

Note further that an alternative way to test the hypothesis is to specify a model that includes a four-way interaction term including the coefficients for: female founder, technology, 
female experimental subject and activism. In a model not presented here but available upon request we did so. The coefficient estimate for the four-way interaction was $2.62(t-r a t i o=2.11)$. Such a model entails 16 degrees of freedom including 6 two-way interaction terms and 4 threeway interactions, rendering the model difficult to interpret in an intuitive manner. Moreover, it is quite data-demanding. ${ }^{10}$ We thus opted for the modeling strategy employed here.

\section{FINDINGS: LABORATORY EXPERIMENT}

Figure 4.

Table 5.

The Kickstarter data in Study 1 revealed that female backers tended to favor projects in publishing and fashion, and disfavor those in technology and games. On average, they also tended to back projects founded by female founders, and this was especially true in technology. The data also demonstrated that female founders are more likely to successfully raise funds even after accounting for the size of the funding raise and characteristics and quality of the pitch, and this effect appears to be driven by choice homophily and female founders operating in technology —an industry category that female backers generally do not back projects in and female entrepreneurs do not found projects in.

As noted above, one possibility explaining these results is that a motivated sub-segment of women is inclined to support other women in industries in which their gender is traditionally under-represented - what we refer to as activist choice homophily. Table 5 presents results from an OLS model based on data derived from our experiment to assess this possibility. The outcome measure is a 5-point ordered response concerning the extent to which the experimental subjects

\footnotetext{
${ }^{10} \mathrm{We}$ also estimated this model with an ordered probit yielding similar results (available upon request).
} 
believed the randomly displayed project (either one in fashion or technology) with a randomly displayed founder (either male or female) was "a good idea."

Model 14 in Table 5 displays coefficients for a model for female experimental subjects; model 15 does so for male subjects. Figure 4 provides a graphical depiction of the key variables. As indicated by the bars in Figure 4 and the three-way interaction term in Table 5 ( $b=1.883$, $P<.01$ (two-tailed test)), female experimental subjects who are coded as activists and who saw the exact same technology project with an image of a female rather than male founder are considerably more likely to agree or strongly agree that the project is a good idea. Interpreted as a predictive margin, the figure is 3.96 on a five point scale, where the intercept is 2.976 . The corresponding estimate for male respondents is insignificant, and statistically differentiable from that for women (Wald- $\chi^{2(1)}=5.69, P<.05$ (two-tailed test) $)$. As a robustness check we duplicated this experiment with the fashion example. And, as noted previously, we ran the model using a pooled sample of male and female respondents and tested the difference in male and female subjects with a four-way interaction. The coefficient estimate for the four-way interaction was 2.62 (t-ratio=2.11). Hence, across different modeling strategies results remain consistent.

These results support our hypothesis, and suggest that women are more likely to view a project favorably in technology if the observable founder is female and they are activists who believe that women are under-represented in technology. This finding supports the existence of activist choice homophily, and suggests that the motivation to help out members of one's disadvantaged class may explain some of the results we found with the field data.

\section{DISCUSSION}

Researchers and policy makers alike have considered what levers can be used to minimize gender disparities in a variety of organizational and institutional settings from 
government to corporate suites. Because entrepreneurs are the source of new organizational cultures and blueprints, minimizing gender disparities in startup rates has implications for a host of other organizational and labor market outcomes in fast growing sectors of the economy.

One proposal to alleviate gender disparities entails increasing female representation in positions of gatekeeping authority. This can mean legislatures at the governmental level, boards of directors in corporations, or partners in venture capital firms. The logic of this approach is rooted in notions of homosocial reproduction, representation, and homophily. A key assumption of this approach is that if more women are placed in decision-making positions they should, in turn, increase the percentage of women in other parts of the industry or organization.

There are, however, countervailing reasons to presume this rationale is incomplete at best and, in some settings, incorrect. First, research on these approaches has shown that representation has complex connections to increased success for women, rather than a direct causal relationship where higher numbers of women lead to greater female success. This is complimented by audit and experimental studies that suggest that women in male-dominated fields (and other minorities in similar positions) may favor members of dominant categories at rates that rival members of those dominant groups (e.g., Nosek, Banaji, and Greenwald, 2002; Moss-Racusin et al., 2012; Milkman, Akinola, and Chugh, 2014). If this is the case, increasing representation will not have its intended ameliorative effect. Moreover, such an approach and the research informing it does not adequately separate and thus understand the mechanisms underlying choice homophily.

In this paper, we test the idea that greater representation of female funders ultimately leads to more successful fundraising by female founders. While we find that women are 
considerably more likely to successful raise capital than male founders, this effect does not appear to be due primarily to representation in itself. In fact, we find the opposite, that women succeed where they are least represented as both funders and founders: in technology, an industry that is traditionally gender-types male.

We argue that this counterintuitive finding is explained by activist choice homophilythat is, choice that is not necessarily based on superficial preference for someone "who looks like me" or because of shared underlying taste. Rather, it is based on the motivation to help someone that shares one's gender overcome perceived structural barriers. Using experimental data, we test the hypothesis that activist women are driving the success of female founders in industries in which women are historically and currently underrepresented. Findings are consistent with this argument. It thus appears that a subpopulation of female backers is comparatively motivated to help female founders succeed in industry categories that are male-dominated, demonstrating the importance of activist choice homophily in the relative advantage of women in crowdfunding.

This finding is important not just because it applies to entrepreneurial finance, but also because it suggests an important mechanism by which the internet can be used to reduce social structural constraints. We find that crowdfunding does appear to reduce structural constraints for female founders seeking capital by removing the traditional gate-keeping function. By democratizing not only access to capital, but also who is able to provide it, we suggest that the internet has potentially large advantages for previously disadvantaged groups by affording access to a wider net of people motivated to help.

This work has some limitations and strengths. Backers on Kickstarter are not the equivalent of investors, and use a variety of criteria to assess their pledges instead of return on 
capital invested. However, crowdfunding is increasingly viewed as an alternative source of fundraising, and that crowd appears to look for signals of quality as investors do (Mollick, 2013), suggesting value in the comparison. Although the laboratory experiment was informed and calibrated based on analyses of Kickstarter data, it is conducted using a sample from a different population. Hence, the experimental results cannot be interpreted as the sole, or even the main, explanation of the patterns observed in the Kickstarter data. Rather, it should be interpreted as a plausible mechanism that can explain how such an empirical pattern may arise. Additionally, while we focus on activism, it is certainly not the only factor of importance. While we are unable to find evidence that the effect is due to factors such as social network size or by women accessing potential funders from greater distances, there may be other mechanisms at work as well. At the same time, the paper has notable strengths to the extent we found similar patterns of behavior in both the field data and in our experiment.

\section{CONCLUSION}

We believe the findings of this research are valuable to both scholars and policy makers. First, descriptively, they suggest that gender disparity in the percentage of female backers relative to males exists on the internet as is the case in formal finance. However, relative gender ratios are far less skewed online. Second, as speculated in the literature concerning the promotion of women to decision-making positions, the presence of female backers explains some of the comparative success of female-founded projects. However, rather than being driven purely by better numerical representation of women in a given industry category, the success of female founders seems to require a subpopulation of female backers that disproportionately support women founder in areas in which women are historically underrepresented - activist choice 
homophily. In this way, our research demonstrates the power of the internet to help ameliorate pervasive structural constraints by affording access to such backers that may be in short supply in a local social area. It also reveals the socially conscious and strategic nature of choice homophilous female backers in our research setting.

Journalists, entrepreneurs, and policy makers have noted the underrepresentation of women in technology as founders, employees, or investors, as well as consistent evidence that female founders seek and receive less venture capital. Prescriptions have thus focused on representation alone, but our findings suggest that activism, as well as representation, is required to change the constraints facing women raising capital. Additionally, this research also has implications for debates concerning how new technological mechanisms such as crowdfunding can facilitate new forms of social organization (Davis, 2013) that can potentially address, or at least help relieve, pervasive and persistent social problems. 


\section{REFERENCES}

Agrawal, A., C. Catalini, and A. Goldfarb

2011 "The geography of crowdfunding." NBER Working Paper No. 16820

Aigner, D. J. and G. G. Cain

1977 "Statistical theories of discrimination in labor markets." Industrial and Labor Relations

Review, 30: 175-87

Aristotle.

1934 "Rhetoric." Aristotle in 23 Volumes. 22: 1371

Arrow, K. J.

1972 "Models of job discrimination." In A.H. Pascal (ed.), Racial Discrimination in Economic Life: 83-102. Lexington, MA: D.C. Heath.

1973 "The theory of discrimination." In Orley Ashenfelter and Albert Rees (eds.),

Discrimination in Labor Markets: 3-33. Princeton, NJ: Princeton University Press.

Baron, J. N. and W. T. Bielby

1980 "Bringing the firm back in: Stratification, segmentation, and th organization of work.

American Sociological Review 45, 737-65.

1985 “Organizational barriers to gender inequality: Sex segregation of jobs and

opportunities.” In Alice S. Rossi (ed.), Gender and the Life Course: 233-251. New York:

Aldine.

Baron J.N., M.T. Hannan, and M.D. Burton

2001 "Labor pains: change in organizational models and employee turnover in young, high-tech firms" American Journal of Sociology, 106(4): 960- 1012.

Baron, J.N. B.S. Mittman, and A.E. Newman

1991 "Targets of opportunity: Organizational and environmental determinants of gender integration within the California civil service, 1979-1985." American Journal of Sociology, 96: 1362-1401.

Baron, R.A., G.D., Markman, and A. Hirsa

2001 "Perceptions of women and men as entrepreneurs: Evidence for differential effects of attributional augmenting." Journal of Applied Psychology, 86(5): 923-29

Bayus, B. and V. Kuppuswamy

2014 "Crowdfunding creative ideas: The dynamics of crowdfunding." Working paper, UNC.

Becker, G. S.

1959 The Economics of Discrimination. Chicago, IL: University of Chicago Press. 
Becker-Blease, J. R. and J. E. Sohl

2007 "Do women-owned businesses have equal access to angel capital?" Journal of Business

Venturing, 22: 503-521.

Beckman C.M. and M.D. Burton

2008 "Founding the future: the evolution of top management teams from founding to IPO." Organization Science, 19(1): 3-24.

Bengtsson, O. and D.H. Hsu

2013 "Ethnic matching in the U.S. venture capital market." Unpublished manuscript.

Bielby, W. T. and J. N. Baron

1986 "Men and women at work: Sex segregation and statistical discrimination." American

Journal of Sociology, 4: 759-799.

Blau, P.

1977 Inequality and Heterogeneity: A Primitive Theory of Social Structure. New York NY: Free Press.

Brush, C.G., A de Bruin, and F. Welter 2009 “A gender-aware framework for women's entrepreneurship.” International Journal of Gender and Entrepreneurship, 1(1): 8-24.

Brush, C., N.M. Carter, E.J. Gatewood, P.G. Greene, and M. Hart 2009 "The Diana project: Women business owners and equity capital: The myths dispelled." Babson College Center for Entrepreneurship Research Paper 2009-11

Burton M.D. and C.M. Beckman

2007 "Leaving a legacy: role imprints and successor turnover in young firms." American Review, 72: 239-66.

Buttner, E.H. and B. Rosen

1989 "Funding new business ventures: Are decision-makers biased against women entrepreneurs?" Journal of Business Venturing, 4: 249-61.

Carter, S., E. Shaw, W. Lam, and E. Wilson

2007 “Gender, entrepreneurship and bank lending." Entrepreneurship Theory and Practice, 42744.

Cain-Miller, C.

2010 "Out of the loop in Silicon Valley.” New York Times (published online April 17).

Carter, N.M. and K.R. Allen

1997 "Size-determinants of women-owned businesses: Choice or barriers to resources." Entrepreneurship and Regional Development, 9(3): 211-20.

Cohen, L.E., J.P. Broschak, and H.A. Haveman 
1998 "And then there were more? The effect of organizational sex composition on the hiring and promotion of managers." American Sociological Review, 63(5): 711-27.

Cohen, P.N. and M.L. Huffman

2007 "Working for the woman? Female managers and the gender wage gap." American

Sociological Review, 72(5): 681-704.

Coleman, S. and A. Robb

2009 "A comparison of new firm financing by gender: Evidence from the Kauffman firm survey data." Small Business Economics, 33: 397-411.

Correll, S.J.

2004 "Constraints into preferences: Gender, status, and emerging career aspirations." American Sociological Review, 9: 93-113.

Davis, G.F.

2013 "After the corporation." Politics \& Society, 41(2): 283-308.

DiTomaso, N.C. Post, and R. Parks-Yancy

2007 "Workforce diversity and inequality: Power, status, and numbers." Annual Review of

Sociology, 33: 473-501.

Duguid, M., D.L. Loyd and P.S. Tolbert

2012 "The impact of categorical status, numeric representation and work group prestige on preference for demographically similar others: A value threat approach." Organization Science, 23: 386-401.

England, P. and S. D. McLaughlin

1979 "Sex segregation of jobs and male-female income differentials." In Rodolfo Alvarez, et al (eds.), Discrimination in Organizations: 189-213. San Francisco, CA: Jossey-Bass.

Fay, M. and L. Williams

1993 "Gender Bias and the Availability of Business Loans." Journal of Business Venturing, 8(4): 363-76.

Fernandez, R. and C. Su

2004 "Space in the study of labor markets." Annual Review of Sociology, 30: 545-569.

Fernandez, R. and J. Greenberg

2013 "Race, network hiring and statistical discrimination." Research in the Sociology of Work, 24: 81-102.

Fuchs-Epstein, C.

1983 Women in Law. New York, NY: Garden City Books.

Gompers, P., V. Mukharlyamov, and Y. Xuan

2012 “The cost of friendship.” NBER Working Paper No. 18141. 
Goodman, L.

2002 "How to analyze survey data pertaining to the time bind and how not to analyze such data." Social Science Quarterly, 83(4): 926-40.

Gorman, E. H.

2005 "Gender stereotypes, same-gender preferences, and organizational variation in the hiring of women: Evidence from law firms.” American Sociological Review, 70: 702-728.

Greenberg, J.

2014 "What you care about or what you know? Which mechanism explains the intergenerational transmission of self-employment? Research in the Sociology of Work, 25: 85-126.

2014 "The networks don't lie: Social relations the performance of different startup types." NYUStern working paper.

Greene, P. and C. Brush

2001 "Patterns of venture capital funding: Is gender a factor?" Venture Capital: An Introduction.

Harrison, R. and C. Mason

2007 "Does gender matter? Women business angels and the supply of entrepreneurial finance." Entrepreneurship Theory and Practice: 445-72.

Heilman, M.E.

2012 "Gender stereotypes and workplace bias." Research in Organizational Behavior, 32: 11335.

Heliman, M.E., A.S. Wallen, D. Fuchs, and M.M. Tamkins

2004 "Penalties for success: Reactions to women who succeed at male tasks." Journal of Applied Psychology, 89: 416-27.

Hogg, M.A. and D.J. Terry

2000 "Social Identity and Self-Categorization Processes in Organizational Contexts." Academy of Management Review, 25(1): 121-40.

Huffman, M.L., P.N. Cohen, and J. Pearlman

2010 "Engendering change: Organizational dynamics and workplace gender desegregation, 1975-2005.” Administrative Science Quarterly, 55(2): 255-77.

Ingram, P. and M.W. Morris

2007 "Do people mix at mixers? Structure, homophily, and the "life of the party."'

Administrative Science Quarterly, 52: 558-85.

Kalev, A., F. Dobbin, and E. Kelley

2006 "Best practices or best guesses? Diversity management and the remediation of inequality." American Sociological Review, 71(4): 589-617.

Kaufman, Z.D., T.W. Kassinger, and H.L. Traeger 
2013 "Democratizing entrepreneurship: An overview of the past, present, and future of crowdfunding." Bloomberg BNA Securities Regulation \& Law Report, 45: 208-17.

Kossinets, G. and D.J. Watts.

2009 "Origins of homophily in an evolving social network." American Journal of Sociology, 115(2): 405-50.

Lazersfeld, P.F and R.K. Merton

1954 "Friendship as a social process: A substantive and methodological analysis." In M. Berger, T. Abel, and C.H. Page (eds.) Freedom and Control in Modern Society. NY, Van Nostrand.

Leiber, $\mathrm{N}$.

2010 "Why venture capital firms need more women partners." Bloomberg Business (June 9).

Lemons, M.A. and M. Parzinger

2007 "Gender schemas: A cognitive explanation of women in technology." Journal of Business

Psychology, 22: 91-8.

Lundqvist, D., A. Flykt, and A. Ohman.

1998 “Karolinska Directed Emotional Faces." Database of Standardized Facial Images.

Psychology Section, Department of Clinical Neuroscience, Karolinksa Hospital. S-171-76

Stockholm, Sweden.

Marlow, S.

2002 "Women and self-employment: A part of or apart from theoretical construct?" International Journal of Entrepreneurship and Innovation, 3(2), 83-91.

McPherson, M. and L. Smith-Lovin

1987 "Homophily in voluntary organizations: Status distance and the composition of face-to-face groups.” American Sociological Review, 52: 370-79.

McPherson, M., L. Smith-Lovin and J.M. Cook

2001 "Birds of a feather: Homophily in social networks." Annual Review of Sociology, 27: 41544.

Milkman, K.L., M. Akinola, and D. Chugh

2014 "Discrimination is not evenly distributed: A field experiment in academia." Wharton working paper.

Merton, R.K.

1987 "Three fragments from a sociologist's notebooks: Establishing the phenomenon, specified ignorance, and strategic research materials." Annual Review of Sociology, 13: 1-29.

Moss-Rascusin, C.A., J.F. Dovidio, VL. Brescoll, M.J. Graham, and J. Handelsman 2012 "Science faculty's subtle gender biases favor male students." PNAS 
Mühlenbruch, B. and M.A. Jochimsen

2013 "Research policy: Only wholesale reform will bring equality." Nature, 495: 40-2.

Nosek, B.A., M.R. Banaji, and A.G. Greenwald.

2002 "Harvesting implicit group attitudes and beliefs from a demonstration web site." Group Dynamics: Theory, Research, and Practice, 6(1): 101-15.

Nosek, B.A., e t al.

2009 "National differences in gender-science stereotypes predict national sex differences in science and math achievement." PNAS, 106(26)

Oosterhof, N.N. and A. Todorov 2008 "The functional basis of face evaluation." Proceedings of the National Academy of Sciences of the USA: 11087-11092.

Pazy, A. and I. Oron

2001 "Sex proportion and performance evaluation among high-ranking military officers." Journal of Organizational Behavior, 22(6): 689-702.

Podolny, J.M.

1993 “A status-based model of market competition." American Journal of Sociology, 98(4):82972.

Petersen, T. and I. Saporta

2004 "The Opportunity structure for discrimination.” American Journal of Sociology, 109(4): $852-901$.

Pfeffer, J.

1983 “Organizational demography.” Research in Organizational Behavior, 5: 299-357.

Reskin, B.F. and D.B. McBrier

2000 "Why not ascription? Organizations' employment of male and female managers."

American Sociological Review, 65: 210-33.

Reskin, B.F., D.B. McBrier, and J.A. Kmec

1999 "The determinants and consequences of workplace sex and race composition." Annual Review of Sociology, 25: 335-61.

Ridgeway, C.

1997 "Interaction and the conservation of gender inequality: Considering employment." American Sociological Review, 62: 218-35.

2009 "Framed before we know it: How gender shapes social relations." Gender \& Society, 23: 832-62. 
2011 Framed by Gender: How Gender Inequality Persists in the Modern World. New York, NY: Oxford University Press.

Robb, A., D. Marom, and O. Sade

2013 "Gender dynamics in crowdfunding: Evidence on entrepreneurs, investors, and deals from Kickstarter." Paper presented at the Academic Symposium on Crowdfunding, Berkeley, CA.

Ruef M., H.E. Aldrich, and N.M. Carter

2003 "The structure of founding teams: homophily, strong ties, and isolation among U.S.

entrepreneurs." American Sociological Review, 68: 195-222.

\section{Ruef M.}

2010 The Entrepreneurial Group: Social Identities, Relations, and Collective Action.

Princeton University Press: Princeton, NJ.

Schwienbacher, A. and B. Larralde

2010 "Crowdfunding of small entrepreneurial ventures." SSRN Electronic Journal.

Shane, S.

2010 "Overlooked when raising capital: Investor preferences." Bloomberg Business week.

Retrieved January 19, 2014.

Shaw, E., S. Carter, and W. Lam

2010 "An integrated view of gender, finance, and entrepreneurial capital: Theory, practice, and policy." Pp. 187-205 in Women Entrepreneurs and the Global Environment for Growth.

Cheltenham, UK: Edward Elgar Publishing.

Simmel, G. 1955 [1908]. Conflict and the Web of Group Affiliations. New York, NY: Free Press.

Stainback, K. and D. Tomaskovic-Devey

2009 "Intersections of power and privilege: Long-term trends in managerial representation."

American Sociological Review, 74(5): 800-20.

Slade, $\mathrm{H}$.

2013 "Why is it so hard for female entrepreneurs to get VC funding? Could crowdfunding be the answer?" Forbes. Retrieved on December 15, 2013. http://www.forbes.com/sites/hollieslade/

Stuart, T. and O. Sorenson

2003a "Liquidity events and the geographic distribution of entrepreneurial activity." Administrative Science Quarterly, 48: 175-201.

$2003 b$ "The geography of opportunity: Spatial heterogeneity in founding rates and the performance of biotechnology firms." Research Policy, 32: 229-253.

Tolbert, P.S. and A.A. Oberfield 
1991 "Sources of organizational demography: Faculty sex ratios in colleges and universities." Sociology of Education 64, 305-15

Tilly, C.

1999 Durable Inequality. Berkeley, CA: University of California Press.

Turco, C.J.

2012 "Cultural foundations of tokenism: Evidence from the leveraged buyout industry."

American Sociological Review, 75(6): 894-913.

Weber, M.

1968 Economy and Society. New York, NY: Bedminister.

White, M.J., T.A. Kruczech, M.T. Brown, and G.B. White

1989 "Occupational sex stereotypes among college students." Journal of Vocational Behavior, 34: $289-98$

Verbrugge, L.M.

1977 "The structure of adult friendship choices.” Social Forces, 56: 576-97.

Whittngton, K.B. and L. Smith-Doerr

2008 "Women inventors in context: Disparities in patenting across academia and industry."

Gender \& Society, 22: 194-218.

Williams, J.C.

2000 Unbending Gender: Why Family and Work Conflict. New York: Oxford University Press.

Wood, Brooks, A., L. Huang, S.W. Kearney, and F.E. Murray

2014 "Investors prefer entrepreneurial ventures pitched by attractive men." Proceedings of the National Academy of Sciences of the United States of America, 111 (10).

Yee, N. and J. Bailenson

2007 "The Proteus effect: The effect of transformed self-representation on behavior." Human

Communication Research, 33(3): 271-90 
Table 1. Summary Statistics and Pair-Wise Correlation Matrix for Kickstarter Data

\begin{tabular}{|c|c|c|c|c|c|c|c|c|c|c|c|c|c|c|c|c|c|c|}
\hline & VARIABLE & Mean & $\begin{array}{l}\text { Std. } \\
\text { Dev. }\end{array}$ & 1 & 2 & 3 & 4 & 5 & 6 & 7 & 8 & 9 & 10 & 11 & 12 & 13 & 14 & 15 \\
\hline 1 & Funded project & 0.319 & 0.466 & 1 & & & & & & & & & & & & & & \\
\hline 2 & $\begin{array}{l}\text { Mean } \% \text { backers } \\
\text { female } \\
\text { Number of founders }\end{array}$ & 0.377 & 0.275 & 0.00 & 1 & & & & & & & & & & & & & \\
\hline 3 & pictured & 1.031 & 0.588 & 0.02 & 0.13 & 1 & & & & & & & & & & & & \\
\hline 4 & Publishing & 0.210 & 0.408 & -0.06 & 0.19 & -0.02 & 1 & & & & & & & & & & & \\
\hline 5 & Fashion & 0.194 & 0.396 & -0.02 & 0.37 & 0.06 & -0.25 & 1 & & & & & & & & & & \\
\hline 6 & Games & 0.198 & 0.399 & 0.03 & -0.33 & 0.05 & -0.26 & -0.24 & 1 & & & & & & & & & \\
\hline 7 & Tech & 0.196 & 0.397 & -0.02 & -0.31 & -0.19 & -0.25 & -0.24 & -0.25 & 1 & & & & & & & & \\
\hline 8 & $\begin{array}{l}\text { At least one male \& } \\
\text { female }\end{array}$ & 0.064 & 0.245 & 0.02 & 0.02 & 0.14 & 0.06 & -0.03 & -0.04 & -0.01 & 1 & & & & & & & \\
\hline 9 & $\begin{array}{l}\text { At least one female, no } \\
\text { males }\end{array}$ & 0.213 & 0.409 & 0.05 & 0.36 & 0.03 & 0.15 & 0.26 & -0.22 & -0.16 & -0.14 & 1 & & & & & & \\
\hline 10 & $\begin{array}{l}\text { At least one male, no } \\
\text { females }\end{array}$ & 0.440 & 0.497 & -0.03 & -0.16 & -0.02 & -0.06 & -0.17 & -0.03 & 0.15 & -0.23 & -0.46 & 1 & & & & & \\
\hline 11 & LN(\$ funding goal) & 4.121 & 0.381 & -0.15 & -0.18 & -0.01 & -0.20 & -0.15 & 0.12 & 0.17 & -0.03 & -0.13 & 0.10 & 1 & & & & \\
\hline 12 & Spelling errors & 0.036 & 0.185 & -0.06 & -0.03 & -0.05 & -0.02 & 0.02 & -0.03 & 0.03 & 0.04 & -0.03 & -0.04 & 0.00 & 1 & & & \\
\hline 13 & Fast update & 0.213 & 0.410 & 0.16 & -0.11 & 0.05 & -0.08 & -0.06 & 0.14 & 0.02 & -0.01 & -0.08 & 0.00 & 0.05 & 0.02 & 1 & & \\
\hline 14 & Project featured & 0.040 & 0.195 & 0.26 & -0.02 & 0.00 & -0.04 & 0.01 & -0.01 & 0.10 & 0.00 & 0.02 & 0.02 & 0.00 & -0.02 & 0.03 & 1 & \\
\hline 15 & \# of Facebook friends & 320.803 & 650.377 & 0.11 & 0.09 & 0.02 & -0.03 & 0.11 & -0.09 & -0.08 & 0.00 & 0.01 & 0.07 & -0.02 & 0.10 & 0.00 & 0.02 & 1 \\
\hline
\end{tabular}

Source: Kickstarter projects with: (a) goals $\geq \$ 5,000$, (b) video, (c) US founders

Note: Coefficients $>.056$ are significant at $P<.05$ (two-tailed test)

For ease of presentation we do not include the interaction terms in this table. Note that there was little evidence of collinearity. Most interaction and main effect terms exhibit low to moderate correlations. No pair-wise correlation exceeds .65 (a correlation matrix including all the interaction terms is available upon request). 
Table 2. Summary Statistics of Variables Used in Experimental Analysis

\begin{tabular}{|c|c|c|c|c|c|c|c|c|c|c|c|c|}
\hline & VARIABLE & Mean & $\begin{array}{l}\text { Std. } \\
\text { Dev. }\end{array}$ & 1 & 2 & 3 & 4 & 5 & 6 & 7 & 8 & 9 \\
\hline 1 & Project is a good idea & 3.475 & 0.980 & 1 & & & & & & & & \\
\hline 2 & Female founder & 0.496 & 0.501 & 0.01 & 1 & & & & & & & \\
\hline 3 & Experiment taker female & 0.655 & 0.477 & 0.11 & 0.04 & 1 & & & & & & \\
\hline 4 & Foreign national & 0.080 & 0.272 & 0.13 & -0.13 & 0.13 & 1 & & & & & \\
\hline 5 & $\begin{array}{l}\text { Prev. backed a crowd-based } \\
\text { project }\end{array}$ & 0.152 & 0.360 & -0.09 & 0.07 & 0.02 & 0.12 & 1 & & & & \\
\hline 6 & Tech experiment & 0.509 & 0.501 & 0.07 & 0.08 & -0.07 & -0.01 & -0.09 & 1 & & & \\
\hline 7 & Fashion experiment & 0.461 & 0.500 & -0.07 & -0.02 & 0.08 & -0.04 & 0.07 & -0.94 & 1 & & \\
\hline 8 & Tech activist & 0.390 & 0.489 & 0.05 & -0.15 & 0.10 & 0.00 & 0.06 & -0.08 & 0.00 & 1 & \\
\hline 9 & Fashion activist & 0.077 & 0.267 & 0.07 & -0.16 & 0.14 & 0.11 & -0.03 & 0.00 & 0.00 & 0.16 & 1 \\
\hline
\end{tabular}

Source: Experiment administered at an elite private school of business in the northeastern region of the US in March, 2014. Note: Coefficients $>.132$ are significant at $P<.05$ (two-tailed test)

For ease of presentation we do not include the interaction terms in this table. Note that there was little evidence of collinearity. Most interaction and main effect terms exhibit low to moderate correlations in the female and male subsamples. No pair-wise correlation exceeds .71 (a correlation matrix including all the interaction terms is available upon request) 
Table 3. ML Fractional Logit Regression Coefficients Predicting \% of Project Backers Female

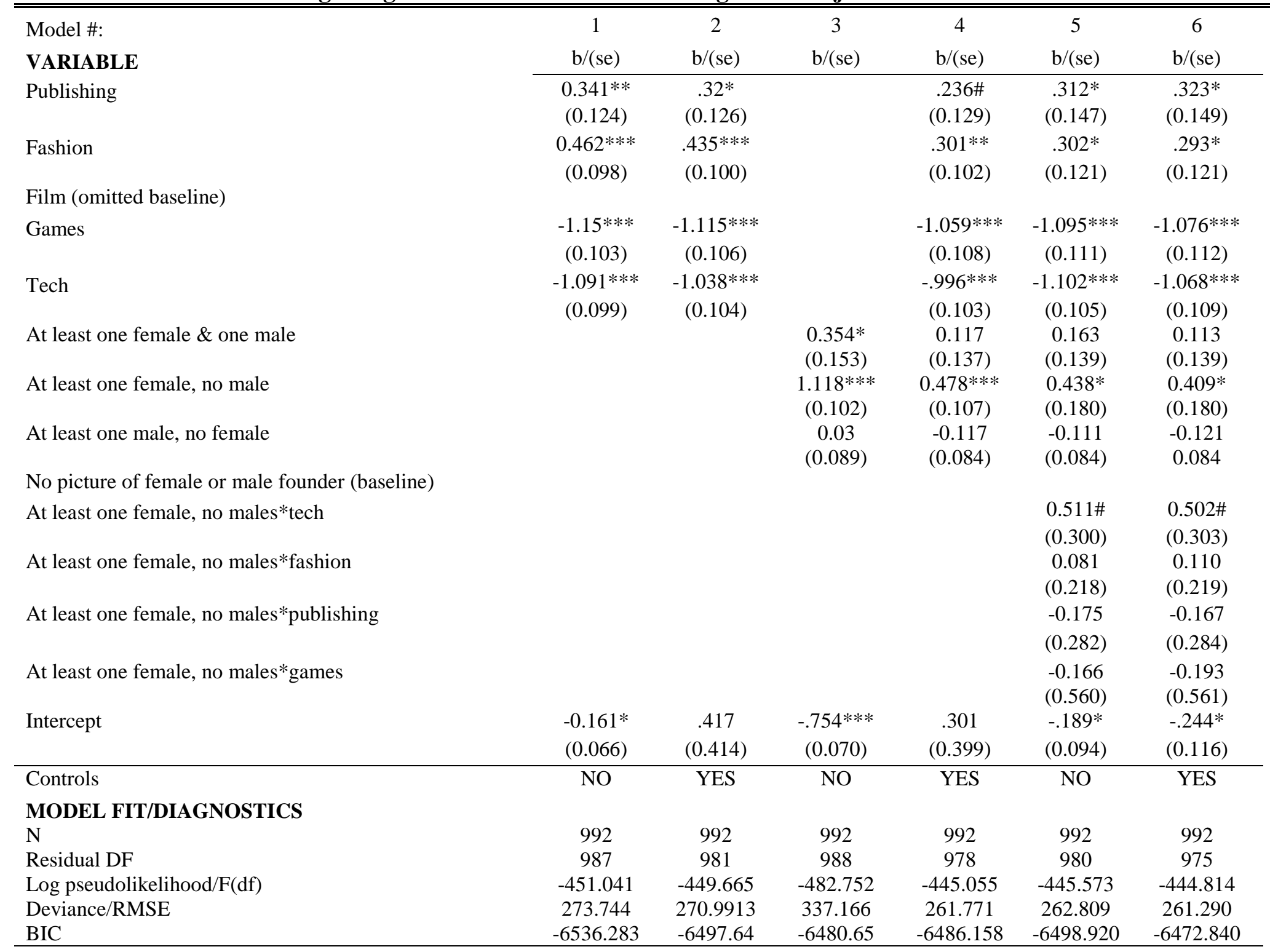

Source: Kickstarter projects with: (a) goals $\geq \$ 5,000$, (b) video, (c) US founders Note: Robust standard errors in parentheses.

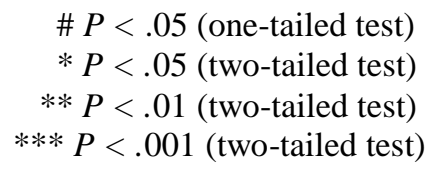


Table 4. Exponentiated Logistic Regression Coefficients Predicting Successful Funding Raise

\begin{tabular}{|c|c|c|c|c|c|c|c|}
\hline $\begin{array}{l}\text { Model \# } \\
\text { VARIABLE }\end{array}$ & $\begin{array}{c}7 \\
\mathrm{OR} /(\mathrm{se})\end{array}$ & $\begin{array}{c}8 \\
\mathrm{OR} /(\mathrm{se})\end{array}$ & $\begin{array}{c}9 \\
\mathrm{OR} /(\mathrm{se})\end{array}$ & $\begin{array}{c}10 \\
\mathrm{OR} /(\mathrm{se})\end{array}$ & $\begin{array}{c}11 \\
\mathrm{OR} /(\mathrm{se})\end{array}$ & $\begin{array}{c}12 \\
\mathrm{OR} /(\mathrm{se})\end{array}$ & $\begin{array}{c}13 \\
\mathrm{OR} /(\mathrm{se})\end{array}$ \\
\hline$\%$ female backers & & & & & $\begin{array}{c}0.802 \\
(0.227)\end{array}$ & $\begin{array}{c}.543 \# \\
(0.172)\end{array}$ & $\begin{array}{c}.684 \\
(0.232)\end{array}$ \\
\hline Publishing & $\begin{array}{l}.611 * * \\
(0.117)\end{array}$ & $\begin{array}{l}.516 * * * \\
(0.105)\end{array}$ & & $\begin{array}{l}.477 * * * \\
(0.100)\end{array}$ & $\begin{array}{l}.432 * * \\
(0.127)\end{array}$ & $\begin{array}{c}.482 * \\
(0.168)\end{array}$ & $\begin{array}{c}.473 * \\
(0.164)\end{array}$ \\
\hline Fashion & $\begin{array}{c}.725 \# \\
(0.139)\end{array}$ & $\begin{array}{l}.546^{* *} \\
(0.115)\end{array}$ & & $\begin{array}{l}.495 * * * \\
(0.108)\end{array}$ & $\begin{array}{l}.502 * * \\
(0.113)\end{array}$ & $\begin{array}{l}.502 * * \\
(0.133)\end{array}$ & $\begin{array}{l}.492 * * \\
(0.130)\end{array}$ \\
\hline \multicolumn{8}{|l|}{ Film (omitted baseline) } \\
\hline Games & $\begin{array}{c}.882 \\
(0.165)\end{array}$ & $\begin{array}{c}.85 \\
(0.173)\end{array}$ & & $\begin{array}{c}.913 \\
(0.190)\end{array}$ & $\begin{array}{c}.783 \\
(0.173)\end{array}$ & $\begin{array}{c}.694 \\
(0.160)\end{array}$ & $\begin{array}{c}.734 \\
(0.170)\end{array}$ \\
\hline Tech & $\begin{array}{c}.717 \# \\
(0.137)\end{array}$ & $\begin{array}{c}.666 \# \\
(0.142)\end{array}$ & & $\begin{array}{c}.688 \# \\
(0.147)\end{array}$ & $\begin{array}{c}.575^{*} \\
(0.129)\end{array}$ & $\begin{array}{l}.464 * * \\
(0.112)\end{array}$ & $\begin{array}{c}.693 \\
(0.230)\end{array}$ \\
\hline At least one female $\&$ one male & & & $\begin{array}{c}1.029 \\
(0.265)\end{array}$ & $\begin{array}{c}1.182 \\
(0.343)\end{array}$ & $\begin{array}{c}0.895 \\
(0.293)\end{array}$ & $\begin{array}{c}.902 \\
(0.299)\end{array}$ & $\begin{array}{c}.919 \\
(0.306)\end{array}$ \\
\hline At least one female, no male & & & $\begin{array}{l}1.401 * \\
(0.244)\end{array}$ & $\begin{array}{l}1.591 * \\
(0.323)\end{array}$ & $\begin{array}{l}1.669 * \\
(0.391)\end{array}$ & $\begin{array}{c}.526 \\
(0.300)\end{array}$ & $\begin{array}{c}.515 \\
(0.296)\end{array}$ \\
\hline At least one male, no female & & & $\begin{array}{c}1.108 \\
(0.165)\end{array}$ & $\begin{array}{c}1.070 \\
(0.173)\end{array}$ & $\begin{array}{c}1.011 \\
(0.174)\end{array}$ & $\begin{array}{c}.999 \\
(0.174)\end{array}$ & $\begin{array}{c}.998 \\
(0.174)\end{array}$ \\
\hline $\begin{array}{l}\text { mean } \% \text { female backers*At } \\
\text { least one female, no male }\end{array}$ & & & & & & $5.99 *$ & $5.895^{*}$ \\
\hline & & & & & & $(4.504)$ & $(4.499)$ \\
\hline $\begin{array}{l}\text { At least one female, no } \\
\text { males*tech }\end{array}$ & & & & & & $4.342 *$ & $6.056^{*}$ \\
\hline & & & & & & $(3.190)$ & $(4.421)$ \\
\hline $\begin{array}{l}\text { At least one female, no } \\
\text { males*fashion }\end{array}$ & & & & & & 1.005 & .998 \\
\hline & & & & & & $(0.512)$ & $(0.510)$ \\
\hline At least one female, no & & & & & & .805 & .809 \\
\hline & & & & & & $(0.509)$ & $(0.512)$ \\
\hline & & & & & & $(1.695)$ & $(1.697)$ \\
\hline $\begin{array}{l}\text { Mean } \% \text { female } \\
\text { backers*tech }\end{array}$ & & & & & & & $.168 \#$ \\
\hline & & & & & & & $(0.166)$ \\
\hline $\begin{array}{l}\text { Controls } \\
\text { MODEL FIT/DIAGNOSTICS }\end{array}$ & $\mathrm{NO}$ & YES & $\mathrm{NO}$ & YES & YES & YES & YES \\
\hline $\mathrm{N}$ & 1237 & 1237 & 1237 & 1237 & 992 & 992 & 992 \\
\hline Wald $\chi^{2(\mathrm{df})}$ & $8.11(4) \#$ & $129.87(10)^{* * *}$ & $4.06(3)$ & $130.68(13) * * *$ & $103.69(14)^{* * *}$ & $109.78(19) * * *$ & $114.25(20)^{* * *}$ \\
\hline Log pseudolikelihood & -770.732 & -684.299 & -772.789 & -681.342 & -567.890 & -563.763 & -562.214 \\
\hline Pseudo $\mathrm{R}^{2}$ & 0.005 & 0.117 & 0.0026 & 0.1206 & 0.118 & 0.125 & 0.127 \\
\hline $\mathrm{BIC}$ & -7230.923 & -7361.067 & -7233.93 & -7345.619 & -5605.249 & -5579.005 & -5575.204 \\
\hline
\end{tabular}

Source: Kickstarter projects with: (a) goals $\geq \$ 5,000$, (b) video, (c) US founders

Note: Robust standard errors using the delta method in parentheses.

Controls include: Ln( \$ funding goal), featured, fast update, \# of founders, \# of Facebook friends, spelling errors

$\# P<.05$ (one-tailed test)

$* P<.05$ (two-tailed test)

$* * P<.01$ (two-tailed test)

$* * * P<.001$ (two-tailed test) 
Table 5. OLS Regression Coefficients Predicting Belief that Project is a Good Idea

\begin{tabular}{|c|c|c|c|c|c|}
\hline $\begin{array}{l}\text { MODEL } \\
\text { Subsample } \\
\text { VARIABLE }\end{array}$ & $\begin{array}{c}14 \\
\text { Female } \\
\mathrm{b} /(\mathrm{se})\end{array}$ & $\begin{array}{c}15 \\
\text { Male } \\
\mathrm{b} /(\mathrm{se}) \\
\end{array}$ & $\begin{array}{l}\text { Wald } \chi^{2(\mathrm{df})} \\
\text { (Equality } \\
\text { of coef.) }\end{array}$ & $\begin{array}{c}16 \\
\text { Female } \\
\mathrm{b} /(\mathrm{se})\end{array}$ & $\begin{array}{c}17 \\
\text { Male } \\
\mathrm{b} /(\mathrm{se}) \\
\end{array}$ \\
\hline Female founder & $\begin{array}{c}0.506 \\
(0.313)\end{array}$ & $\begin{array}{l}-0.512 \\
(0.555)\end{array}$ & 3.04(1)\# & $\begin{array}{l}-0.001 \\
(0.255)\end{array}$ & $\begin{array}{c}0.115 \\
(0.313)\end{array}$ \\
\hline Tech & $\begin{array}{c}0.883 * * \\
(0.313)\end{array}$ & $\begin{array}{c}-.202 \\
(0.424)\end{array}$ & $4.99(1)^{*}$ & & \\
\hline Tech activist & $\begin{array}{l}0.594 \# \\
(0.348)\end{array}$ & $\begin{array}{l}-.276 \\
(0.460)\end{array}$ & $2.68(1)$ & & \\
\hline Female founder*tech & $\begin{array}{l}-1.031 * \\
(0.397)\end{array}$ & $\begin{array}{c}.671 \\
(0.647)\end{array}$ & $5.96(1)^{*}$ & & \\
\hline Female founder*tech activist & $\begin{array}{c}-.786 \# \\
(0.472)\end{array}$ & $\begin{array}{c}.892 \\
(0.844)\end{array}$ & 3.58(1)\# & & \\
\hline Tech*tech activist & $\begin{array}{c}-1.179 * \\
(0.476)\end{array}$ & $\begin{array}{c}.658 \\
(0.631)\end{array}$ & $6.35(1)^{*}$ & & \\
\hline Female founder*tech*tech activist & $\begin{array}{c}1.883 * * \\
(0.684)\end{array}$ & $\begin{array}{l}-0.964 \\
(1.105)\end{array}$ & $5.69(1)^{*}$ & & \\
\hline Fashion & & & & $\begin{array}{c}-.259 \\
(0.296)\end{array}$ & $\begin{array}{c}-.038 \\
(0.332)\end{array}$ \\
\hline Fashion activist & & & & $\begin{array}{c}.447 \\
(0.337)\end{array}$ & $\begin{array}{c}.065 \\
(0.382)\end{array}$ \\
\hline Female founder*fashion & & & & $\begin{array}{c}.132 \\
(0.385)\end{array}$ & $\begin{array}{c}-.329 \\
(0.502)\end{array}$ \\
\hline Female founder*fashion activist & & & & $\begin{array}{l}-.823 \# \\
(0.487)\end{array}$ & -- \\
\hline Fashion*fashion activist & & & & $\begin{array}{c}-.319 \\
(0.596)\end{array}$ & -- \\
\hline Female founder*fashion*fashion activist & & & & $\begin{array}{c}1.147 \\
(0.918)\end{array}$ & -- \\
\hline Intercept & $\begin{array}{c}2.976^{* * * *} \\
0.264\end{array}$ & $\begin{array}{c}3.571 * * * \\
(0.379)\end{array}$ & & $\begin{array}{c}3.532 * * * \\
(0.279)\end{array}$ & $\begin{array}{c}3.94 * * * \\
(0.433)\end{array}$ \\
\hline MODEL FIT/DIAGNOSTICS & & & & & \\
\hline $\mathrm{N}$ & 142 & 76 & & 142 & 76 \\
\hline Wald $\chi^{2(\mathrm{df})}$ & $3.98(13)^{* * *}$ & $2.98(13)^{* *}$ & & $\cdot$ & $2.91(11)^{* *}$ \\
\hline Root MSE & 0.942 & 1.044 & & 0.968 & 1.026 \\
\hline $\mathrm{R}^{2}$ & 0.147 & 0.095 & & 0.106 & 0.099 \\
\hline
\end{tabular}

Source: Experiment administered at an elite private school of business in the northeastern region of the US in March, 2014.

Note: Robust standard errors in parentheses. "--" denotes omitted due to small cell.

Controls include: Ethnicity dummies, citizenship status, and whether respondent has backed a crowdfunding project

$\# P<.05$ (one-tailed test)

$* P<.05$

$* * P<.01$

$* * * P<.001$ (two-tailed tests) 
Figure 1A. Percent of Female Founders Within Industry Category

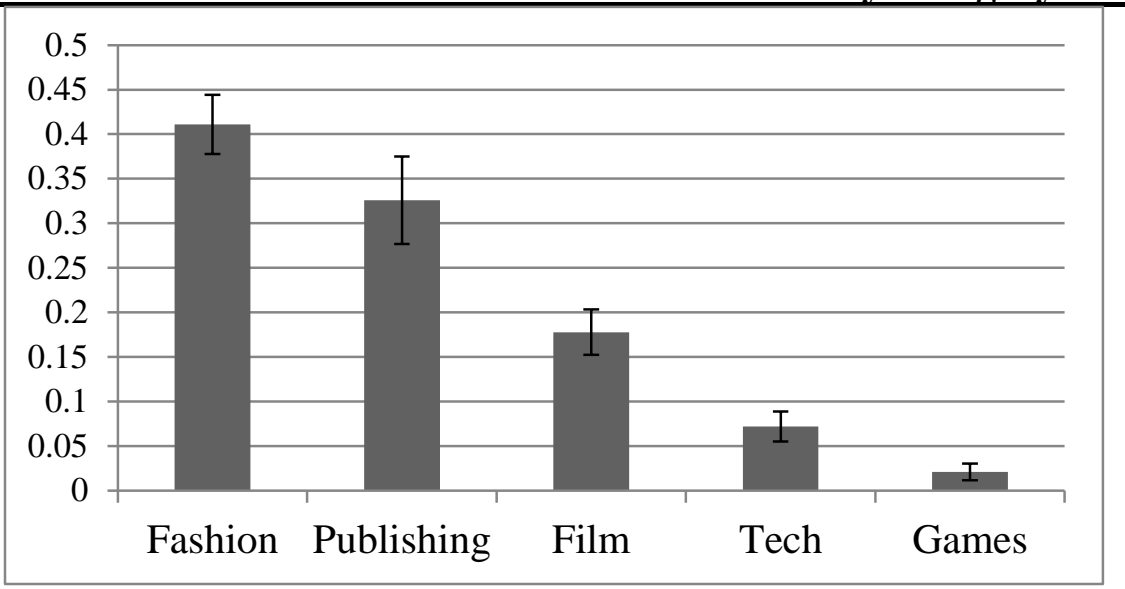

Note: Bars represent standard errors. Excludes mixed gender teams and those with no gender evident (e.g., those that only display corporate logos but no founders). Hence, bars indicate what percentage all female teams constitute of each industry category. Unconditional figures presented.

\section{Figure 1B. Percent Female Backers By Industry Category}

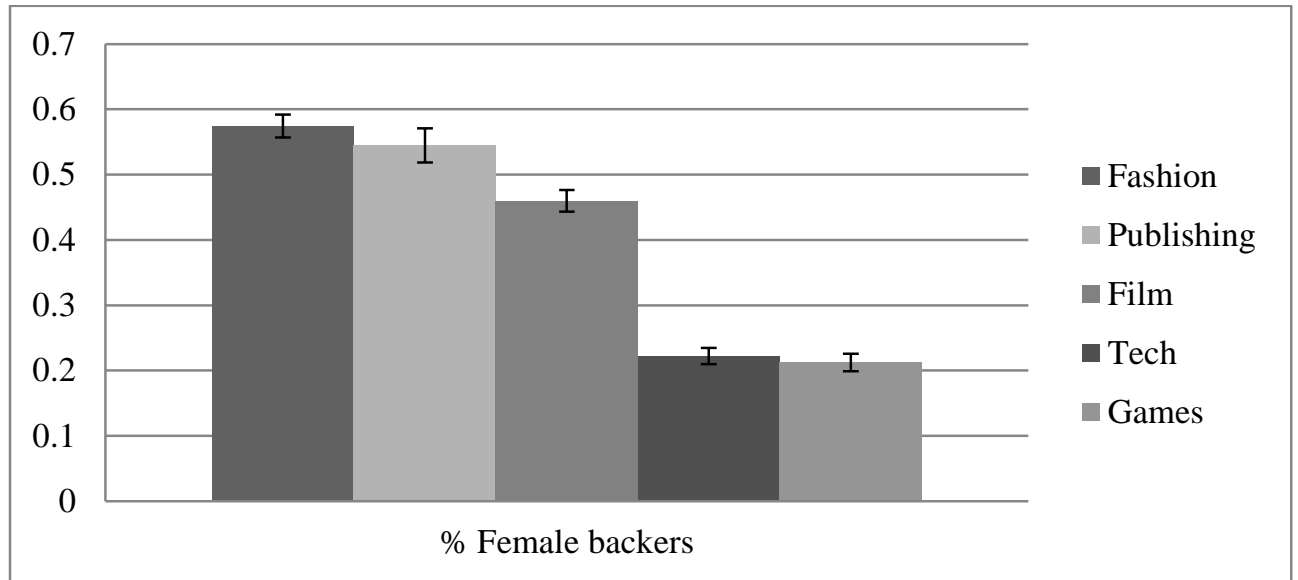

(N=992) Note: Bars represent standard errors. Unconditional figures presented. 


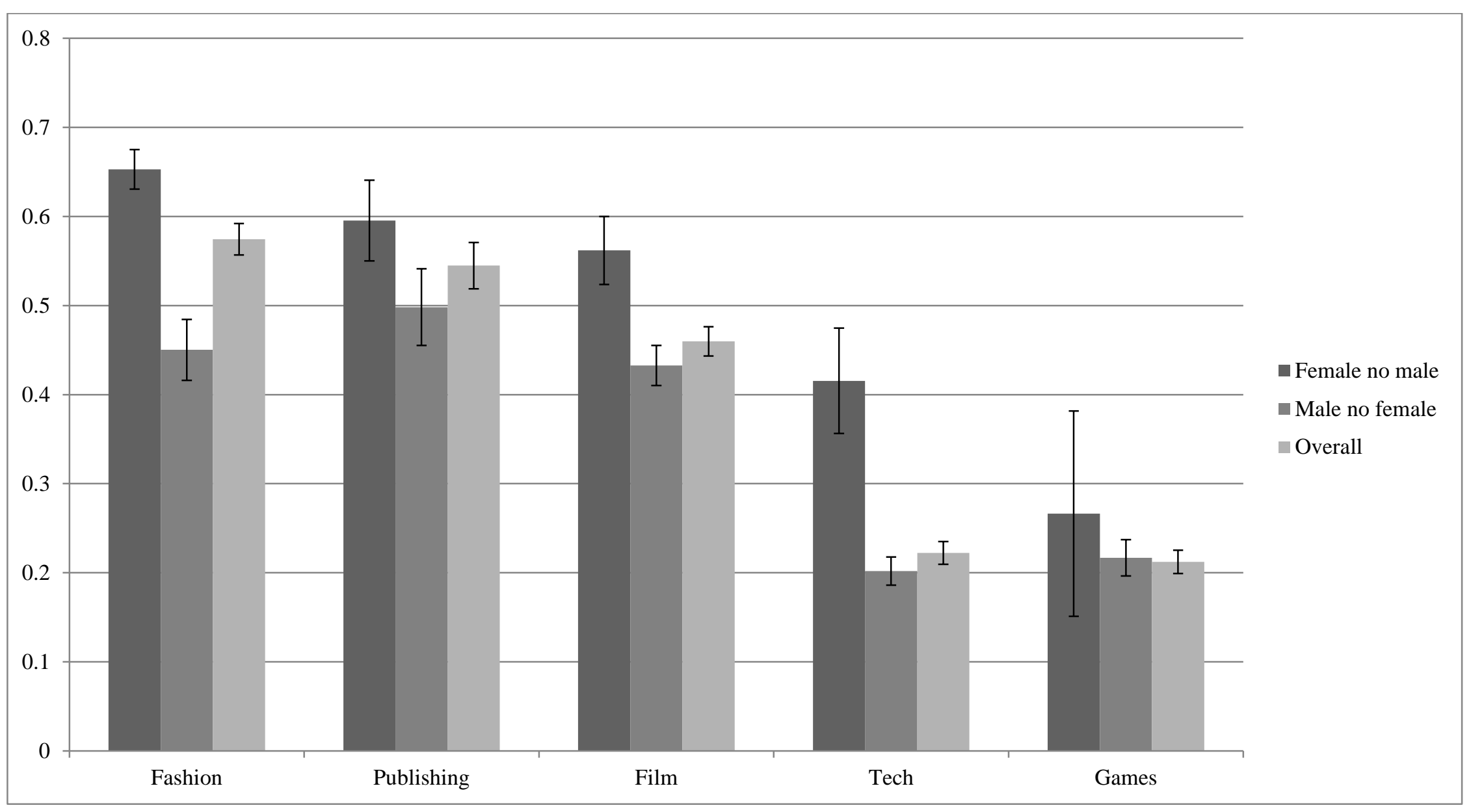

Source: Kickstarter $(\mathrm{N}=992)$

Note: Bars represent standard errors. Overall category denotes sample average and includes mixed-gender teams and projects where No founder's gender was obvious (e.g., just a corporate logo was presented). Unconditional figures presented. 


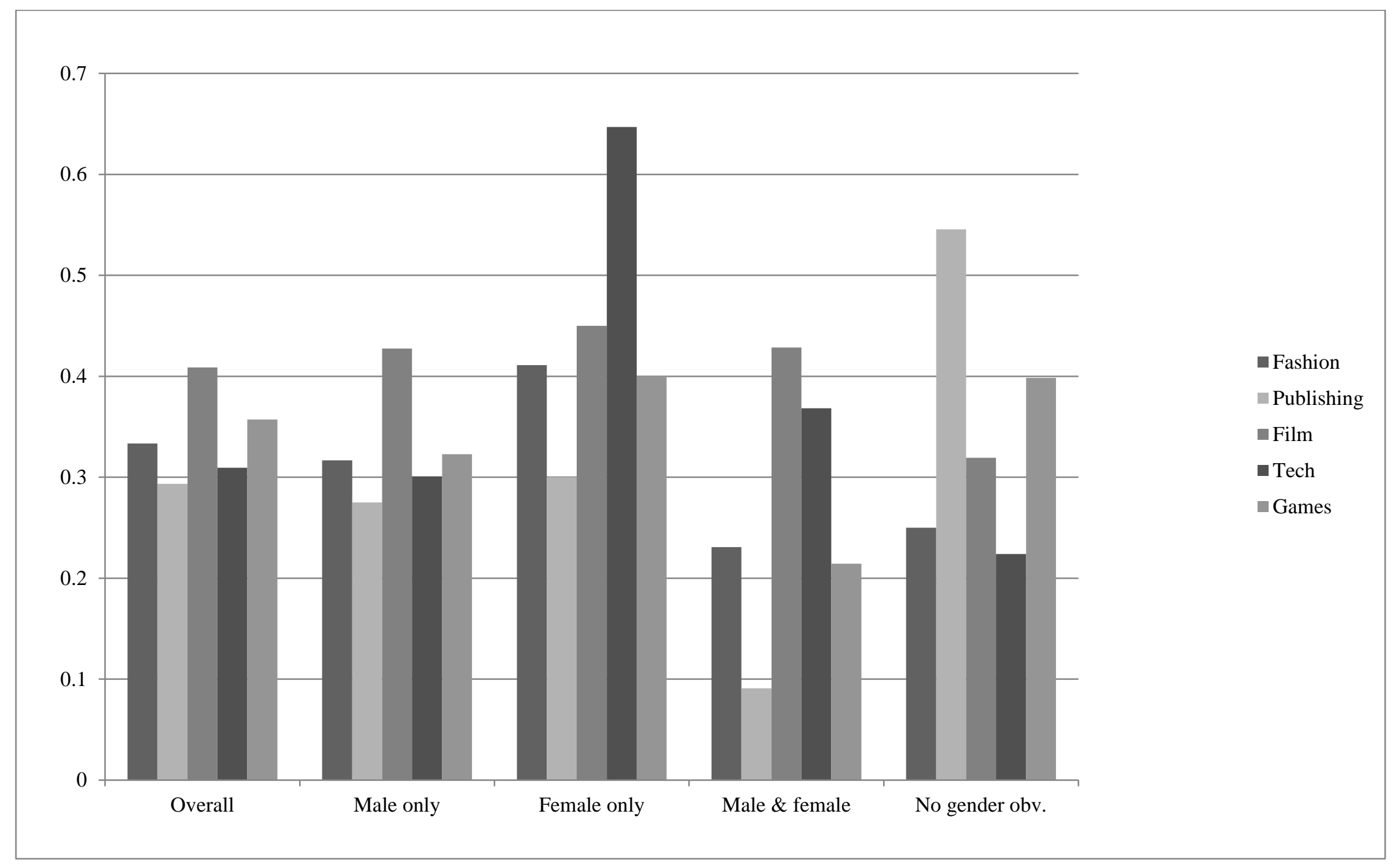

Source: Kickstarter

Note: Unconditional figures presented. 
Figure 4. Marginal Effects from OLS Regression Predicting a Technology Project is a Good Idea based on Experimentally Manipulated Gender of Founder, and Activist Orientation of Female Experimental Subject

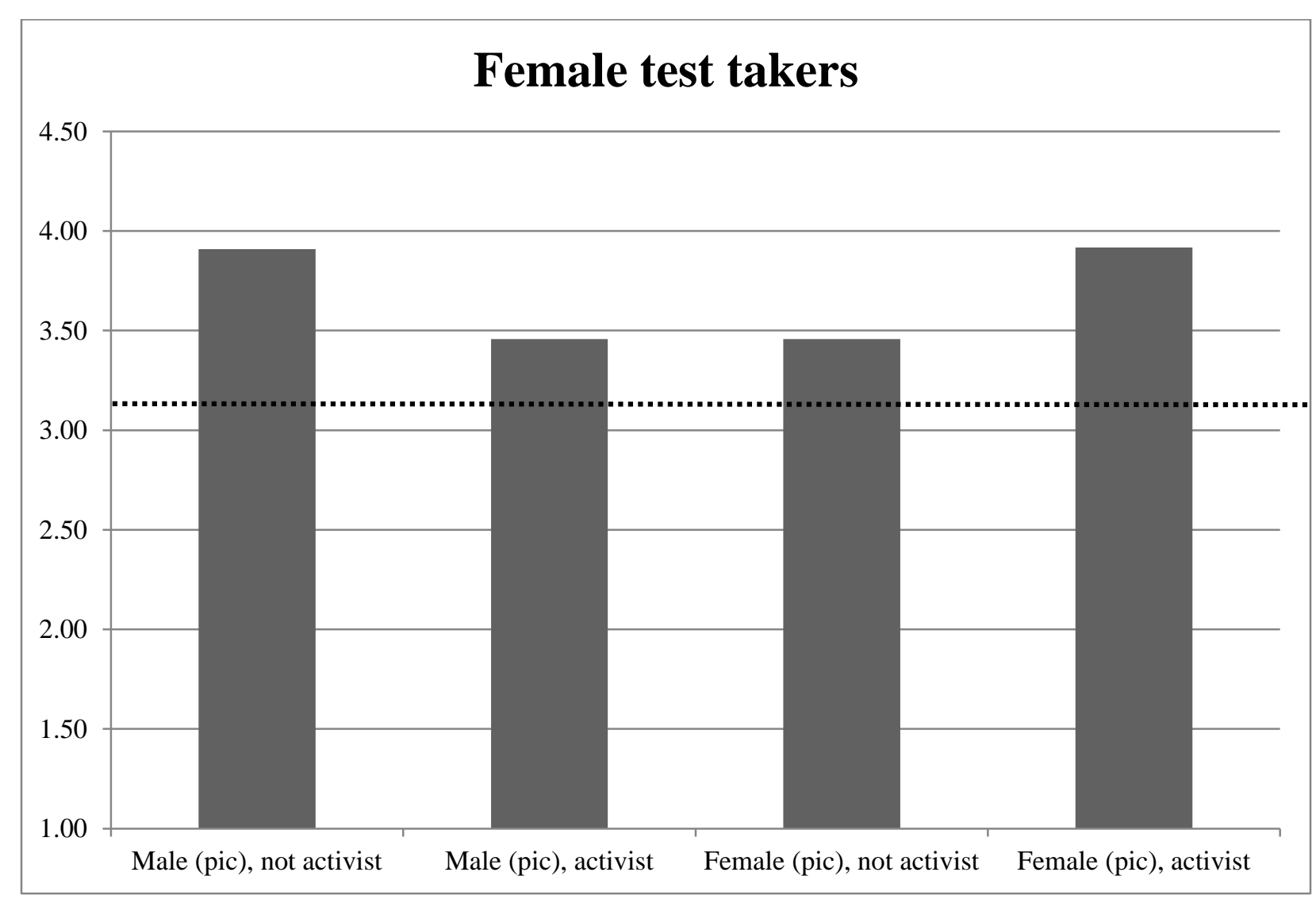

Source: Experiment administered at an elite private school of business in the northeastern region of the US in March, 2014

Note: Conditional figures presented. Bars represented margin on five point scale of a female experimental subject who ha (did not have) an activist orientation and viewed a project founded by a female or male entrepreneur. Dashed line denotes baseline effect. 


\section{APPENDIX}

Table A1. Robustness Checks and Ancillary Analyses

Outcome measure:

Mean \% backers female Quasi-likelohood

Model type:

Frac. Logit

ML Frac.

$\underline{\text { Ln(distance) }}$ friends)

$\underline{\text { Ln(Facebook }}$

VARIABLE

Win

b/(se)

OLS Logit +

distance

OLS

Mean \% female backers

$\mathrm{b} /(\mathrm{se}) \quad \mathrm{b} /(\mathrm{se})$

OLS

$\mathrm{b} /(\mathrm{se})$

$0.806^{*}$

$(0.367)$

$-1.13$

$-.906$

Publishing

.2

(0.846)

(0.883)

Publishing

(0.138)

$.053^{*}$

.152

$1.549^{*}$

0.939

$.271 *$

$(0.032)$

(0.124)

(0.641)

(0.661)

(0.108)

$(0.025)$

$.257 * *$

$1.727 * * *$

0.9

(0.098) (0.487)

$(0.561)$

Film (omitted baseline)

Games

$-1.08 * * *$

(0.106)

$-.232 * * *$

(0.022)

Tech

$-1.017 * * *$

$-.216^{* * *}$

$1.046 * * *$

$2.193 * * *$

$-0.273$

(0.105)

(0.022)

(0.102)

(0.537)

(0.538)

At least one female $\&$ one male

0.020

$(0.149)$

0.008

0.187

0.266

$1.9^{* *}$

At least one female, no male

$0.497 * * *$

(0.028)

(0.139)

(0.655)

(0.682)

(0.111)

$0.117 * * *$

$0.489 * * *$

0.745

0.284

At least one male, no female

$$
-0.112
$$

(0.025)

(0.107)

(1.511)

(1.525)

(0.084)

$-0.027$

$-0.074$

$-0.301$

$1.254 * *$

$(0.017)$

(0.098)

(0.374)

(0.414)

mean $\%$ female backers*at least one female, no males

$-0.851$

(1.817)

1.547

At least one female, no males*tech

$-0.787$

(1.192)

0.804

(1.445)

At least one female, no males*fashion

$-0.957$

$-0.3$

(1.027)

(1.118)

At least one female, no

0.541

$-0.957$

males*publishing

(1.081)

(1.295) 
At least one female, no males*games

Ln(median distance btw. backers and founder)

\begin{tabular}{|c|c|c|c|c|}
\hline & & $\begin{array}{c}-0.018 \# \\
(0.010)\end{array}$ & -- & $\begin{array}{c}.0236 \\
(0.047)\end{array}$ \\
\hline .191 & $.494 * * *$ & 0.192 & 1.042 & $-3.516 \#$ \\
\hline$(0.406)$ & $(0.085)$ & $(0.460)$ & (1.710) & $(2.123)$ \\
\hline YES & YES & YES & YES & YES \\
\hline \multirow[t]{3}{*}{966} & 966 & $\begin{array}{l}660 \\
645\end{array}$ & 678 & 678 \\
\hline & & - & & \\
\hline & $45.5(14)^{* * *}$ & 297.1403 & $4.95(18,659)^{* * *}$ & $1.73(18,659)^{*}$ \\
\hline \multirow[t]{2}{*}{1.137} & 0.221 & 136.782 & 3.62 & 4.226 \\
\hline & -6728.537 & 4050.712 & -633.631 & -423.955 \\
\hline
\end{tabular}

Source: Kickstarter projects with: (a) goals $\geq \$ 5,000$, (b) video, (c) US founders

Intercept

Controls

1.710

MODEL FIT/DIAGNOSTICS

$\mathrm{N}$

Residual DF

$\log$

pseudolikelihood/F(df)

Deviance/RMSE

Note: Robust standard errors in parentheses.

"-" denotes omitted due to small cell size.

Controls include: $\operatorname{Ln}(\$$ funding goal), featured, fast update, \# of founders, \# of Facebook friends, spelling errors $\# P<.05$ (one-tailed test)

$* P<.05$ (two-tailed test)

** $P<.01$ (two-tailed test)

*** $P<.001$ (two-tailed test) 
Table A2. Ordered Probit Coefficients Predicting Level of Agreement that Project is a Good Idea

Model \#

Subsample

Female $\quad$ Male

VARIABLE

Female founder

\begin{tabular}{cc}
$\mathrm{b} /(\mathrm{se})$ & $\mathrm{b} /(\mathrm{se})$ \\
\hline $0.664 \#$ & -.584
\end{tabular}

(0.344)

$(0.552)$

Tech

$1.069 * *$

$-.219$

$5.08(1)^{*}$

$(0.380)$

$(0.441)$

Tech activist

0.648

$-.219$

$2.05(1)$

(0.397)

$(0.511)$

Female founder*tech

$-1.327 * *$

.754

$5.85(1)^{*}$

(0.495)

(0.693)

Female founder*tech activist

$-.79$

.983

(0.895)

(0.534)

.752

$(0.777)$

(0.547)

$-.94$

Wald $\chi^{2}$ testing equality of female and male

Tech*tech activist

$2.183^{* *}$

(1.186)

$(0.780)$

$-2.07$

$(0.337)$

(0.409)

Cut 2

$-0.391$

$-.656$

(0.271)

(0.311)

Cut 3

0.133

$-.25$

(0.268)

$(0.305)$

Cut 4

1.859

1.658

(0.301)

(0.361)

Controls

YES

YES

\section{MODEL FIT/DIAGNOSTICS}

$\mathrm{N}$

142

76

LR- $\chi^{2(\mathrm{df})}$

Appx. $\chi^{2(\mathrm{df})}$ of $=$ coefficients across

$17.74(9)^{*} \quad 5.61(9)$

response categories

$35.42(26), \mathrm{ns}$

$33.6(22), \mathrm{ns}$

Log pseudolikelihood

$-169.674$

$-89.522$

Pseudo $\mathrm{R}^{2}$

0.050

0.030

Source: Experiment administered at a private school of business in the northeastern region of the US in March, 2014

Controls include: Citizenship status and whether respondent has backed a crowdfunding project

$$
\begin{array}{r}
\# P<.05 \text { (one-tailed test) } \\
* P<.05 \text { (two-tailed test) } \\
* * P<.01 \text { (two-tailed test) } \\
* * * P<.001 \text { (two-tailed test) }
\end{array}
$$




\section{Exhibit A. Example Project Page}

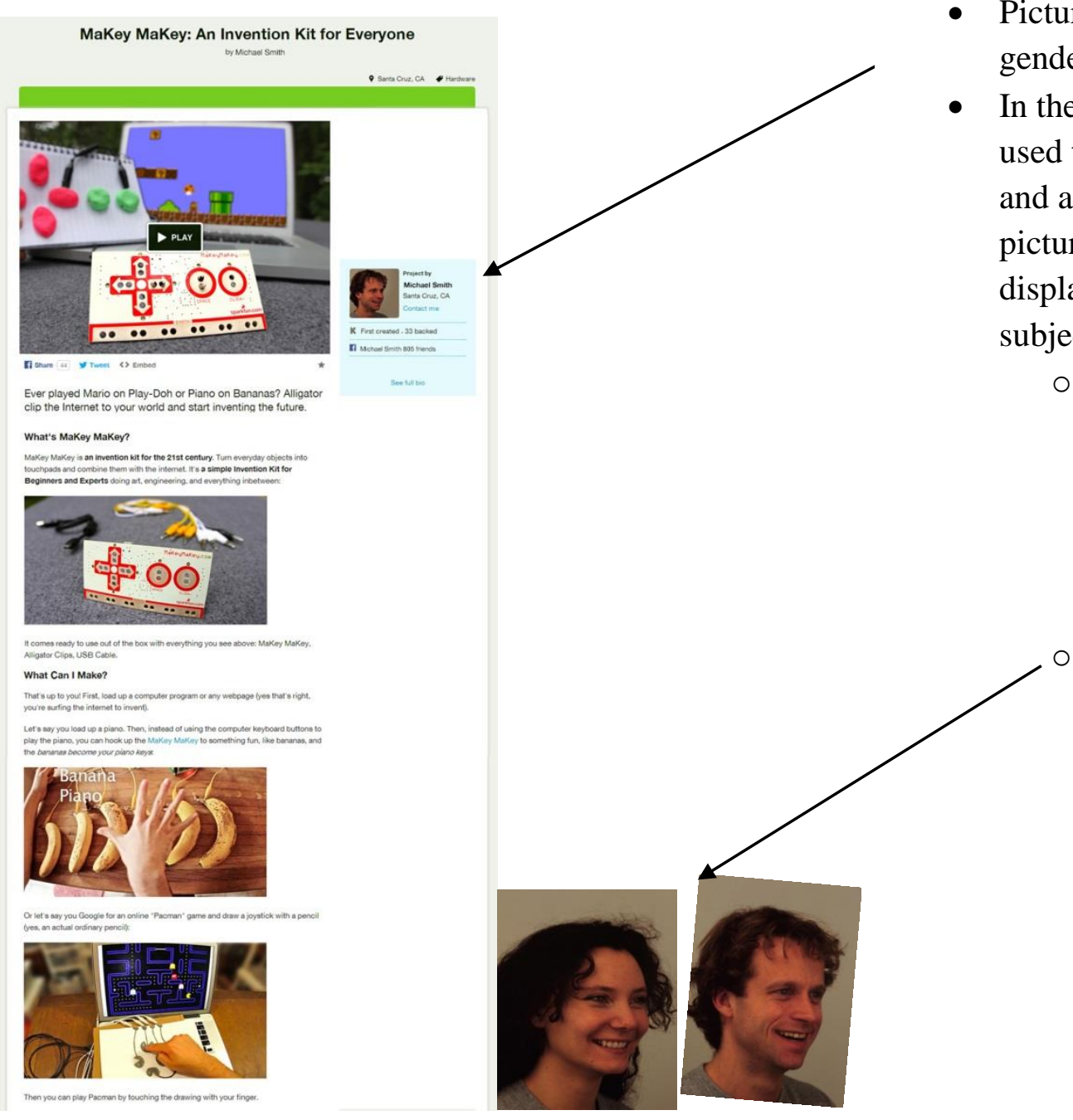

Note: Scale reduced for presentation
- Picture of founder used for gender coding used the same real-word used the same real-world project and altered the first name and picture of the founder randomly displayed to experimental subjects

- To control for name effects we used the two most popular female and male names of the age of founders displayedJessica and Michael To control for founder attractiveness, we employed photographs deemed of average attractiveness in research concerning facial evaluation (Lundqvist, Flykt, and Ohman, 1988; Oosterhof and Todorov 2008); note also that male and female models have the same relative pose, smile, and the same color t-shirt to further control for heterogeneity 